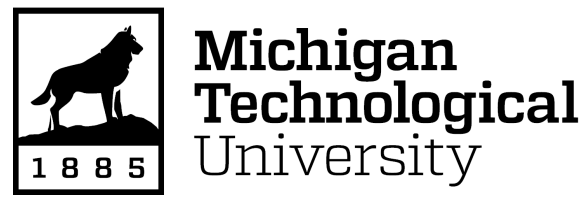

Michigan Technological University Digital Commons @ Michigan Tech

Dissertations, Master's Theses and Master's Reports

2017

\title{
WETLAND POLICY DESIGN IN THE UPPER GREAT LAKES STATES: CASES OF POLICY SUCCESS AND FAILURE
}

Miranda N. Smith

Michigan Technological University, mnaho@mtu.edu

Copyright 2017 Miranda N. Smith

\section{Recommended Citation}

Smith, Miranda N., "WETLAND POLICY DESIGN IN THE UPPER GREAT LAKES STATES: CASES OF POLICY SUCCESS AND FAILURE", Open Access Master's Thesis, Michigan Technological University, 2017.

https://doi.org/10.37099/mtu.dc.etdr/466

Follow this and additional works at: https://digitalcommons.mtu.edu/etdr

Part of the Environmental Policy Commons 


\title{
WETLAND POLICY DESIGN IN THE UPPER GREAT LAKES STATES: CASES OF POLICY SUCCESS AND FAILURE
}

\author{
By \\ Miranda N. Smith
}

\author{
A THESIS \\ Submitted in partial fulfillment of the requirements for the degree of \\ MASTER OF SCIENCE \\ In Environmental and Energy Policy \\ MICHIGAN TECHNOLOGICAL UNIVERSITY \\ 2017 \\ (C) 2017 Miranda N. Smith
}


This thesis has been approved in partial fulfillment of the requirements for the Degree of MASTER OF SCIENCE in Environmental and Energy Policy.

\section{Department of Social Sciences}

Thesis Advisor: $\quad$ Dr. Richelle Winkler

Committee Member: $\quad$ Dr. Donald Lafreniere

Committee Member: Dr. Adam Wellstead

Department Chair: Dr. Hugh Gorman 


\section{Table of Contents}

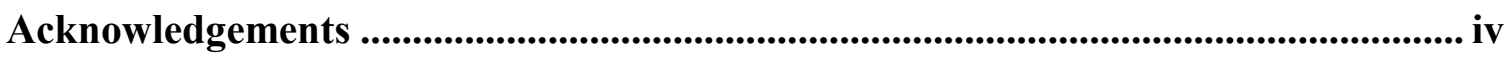

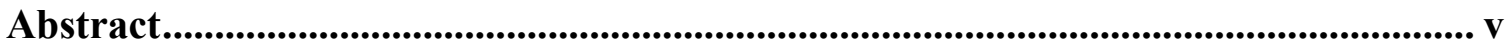

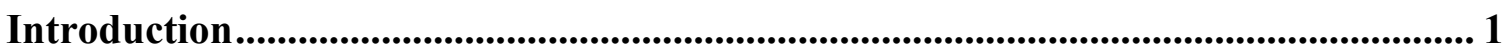

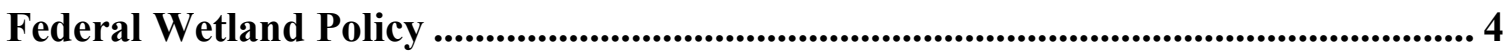

Establishing Wetland Change in Michigan, Minnesota \& Wisconsin .......................... 6

Literature Review ............................................................................................................ 11

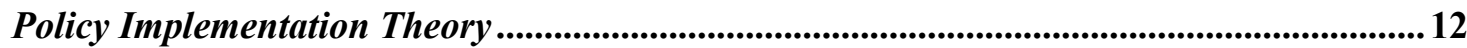

Wetland Policy Design and Implementation ....................................................................................... 15

Population and Agriculture ............................................................................................................ 17

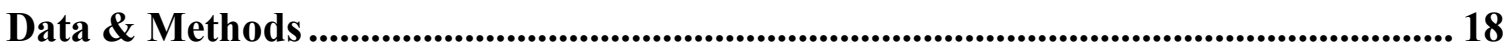

Comparing Policy Design in Michigan, Minnesota, and Wisconsin .......................................20

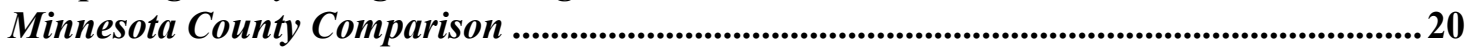

Results: State-level Comparison ........................................................................... 24

Michigan's Wetland Policies............................................................................................................. 25

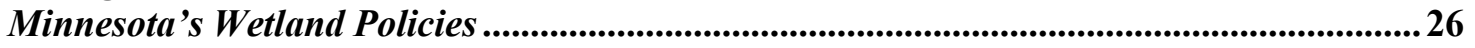

Wisconsin's Wetland Policies................................................................................................................ 28

Summary and Comparison for Three States' Wetland Policies.............................................. 29

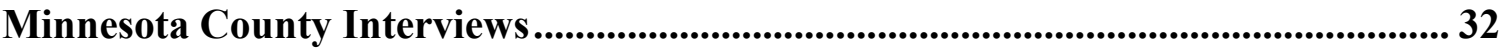

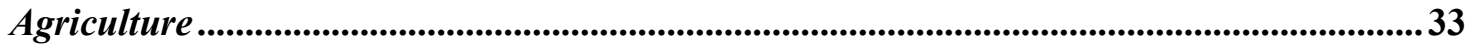

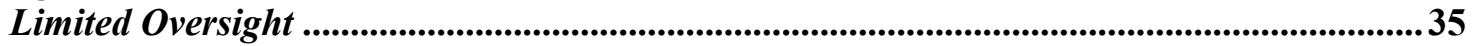

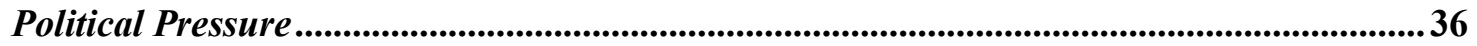

Minnesota County-level Comparison............................................................................. 39

Discussion................................................................................................... 42

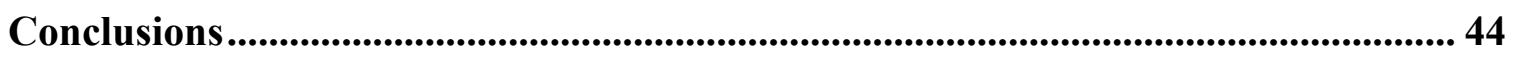

References................................................................................................................. 47

Appendix A. Interview Questions..................................................................................... 52

Appendix B. Regression Analysis ...........................................................................55 


\section{Acknowledgements}

I would first like to thank my advisor, Dr. Richelle Winkler, for her unwavering support during all of my endeavors in the Environmental and Energy Policy Master's program at Michigan Technological University. She has been an amazing mentor for me, and has provided me with experience, knowledge, and most importantly a greater understanding of complex issues around the world. I truly appreciate all she has done for me to finish this thesis and Master's program.

I want to thank Dr. Donald Lafreniere, Dr. Adam Wellstead, and Dr. Audrey Mayer for all of their time, help, and thoughtful suggestions. I would like to express my gratitude to Dr. Donald Lafreniere for joining my committee during a very busy time of the year. I also want to give a special thank you to Dr. Adam Wellstead for making a note on a paper I submitted in his undergraduate natural resource policy class, suggesting that I look into the Environmental and Energy Policy MS program, which ultimately led to this thesis.

I also want to thank my parents, Randy and Laurie Aho, for all of their encouragement and support throughout all my years of schooling. Lastly, I want to thank my husband, Cole, for his patience and everything he has sacrificed to make finishing this thesis easier for me.

Miranda Smith

July, 2017 


\begin{abstract}
The national goal of "no net loss" of wetlands in the United States has significantly lowered the rate of wetland loss, but wetlands are still being impacted in some areas. Many states have their own policies in place to protect wetlands aside from the main federal policy, Section 404 of the Clean Water Act, and those policies are implemented in different ways by different levels of government. This research focuses on wetland policy in the Upper Great Lakes states comparing Michigan, Minnesota, and Wisconsin. Wetland policy and implementation practices vary from state to state, with wetland approval being more devolved to the local county level within the state of Minnesota. This thesis aims to describe the extent to which wetland loss is still occurring in the Upper Great Lakes states, and then to understand how wetland policy design and implementation contribute to policy failure in Minnesota.
\end{abstract}

First, calculating wetland area change at the county-level using NLCD data, shows that there was greater wetland loss in Minnesota from 2001 to 2011 than in Wisconsin or Michigan. A Moran's I test showed a hotspot where wetland loss is clustered in the southeast part of Minnesota, especially in the Minneapolis-St. Paul (MSP) metropolitan area and surrounding counties. Seeing such spatial differences in wetland area change raises the question of whether and how state and local-level policies impact wetland loss. The bulk of this thesis takes a nested comparative analysis of wetland policy levels of implementation in each state followed by related factors that impact whether counties lose wetlands in Minnesota using Mill's Methods to understand wetland policy failure. 
The county-level comparative analysis compared wetland loss to oversight, political pressure, agricultural pressure, and population pressure between counties in the hotspot near the MSP metropolitan area. Four interviews with wetland-permitting decision-makers in four of the counties informed the analysis with factors to consider. The results indicated that some counties outside the seven-county MSP planning region lost more wetlands than those within it, despite the population and development pressure within the metro area. The Watershed Management Organizations required of the seven counties provide oversight on wetland-permitting decisions and reduce wetland loss. Political pressure exerted on elected officials was shown to cause wetland loss outside the seven-county MSP planning/oversight region. The politicized decisionmaking process for elected officials increases the likelihood of conflicting goals with wetland policy, which can result in wetland loss. These findings suggest that wetland policy is a failure in Minnesota because of the design of the Wetland Conservation Act. It is an intervention and institutional failure, because the wetland policies are not properly integrated, resulting in policy inconsistencies across counties and negative wetland impacts. There is insufficient monitoring in places, particularly outside the seven-county planning region where Watershed Management Organizations are not required. This suggests that designing policy for multi-agency involvement could minimize local conflict and issues with oversight, and, therefore, may be a more effective way to implement wetland policy. 


\section{Introduction}

Wetlands provide many economic, cultural, and ecological benefits, such as flood protection and erosion control by controlling water flow, and provide water filtration through wetland vegetation (Millennium Ecosystem Assessment 2005, USEPA 2016), functioning as "nature’s kidneys” (Sargent \& Carter 1999, Reyer et al. 2009). As water flows through wetlands, the vegetation slows the flow, allowing sediment and pollutants to settle, and reducing the risk of flooding and erosion.

Wetland ecosystems contain rich biodiversity and wildlife habitat, and they are home to a variety of sensitive, rare, and important plant and animal species. The pitcher plant and sundew, in particular, are two plant species that can only be found in bogs and fens. Northern white-cedar, a tree species that provides desirable, rot-resistant timber for harvesting, grows primarily in swamps and bottomlands (Burns \& Honkala 1990).

Wetlands are also important for prey species as places to nest, feed, and rear their young away from predators (Sargent \& Carter 1999). The piping plover and copperbelly water snake are two endangered species that use wetlands as habitat (USFWS 2015).

Many food products are grown in wetland environments, including wild rice, blueberries, and cranberries, as well as other plant products, including marsh hay and timber (Sargent \& Carter 1999). They also provide many opportunities for recreation, such as hunting, fishing, hiking, canoeing, and bird watching, providing enjoyment for people in the outdoors (Sargent \& Carter 1999).

Some wetland types, such as coastal wetlands and peatlands, can act as carbon sinks. Plants in coastal wetlands tend to be fast-growing species, allowing them to 
sequester large amounts of carbon dioxide (NOAA 2012). Plants that grow in peatlands are typically slow growing, but peatlands store large amounts of carbon underground in the form of peat soil (Lindsay 2010). The anaerobic soils of coastal wetlands, peatlands, and many other wetland types allow carbon to be stored for long periods of time (NOAA 2012, Lindsay 2010). These processes help to reduce carbon dioxide in the atmosphere, mitigating a contributing factor of climate change.

Wetlands are also important to the culture of many Native American tribes. Historically, Native Americans used open water wetlands as transportation corridors, while marshes and swamps were used as hunting grounds and areas to grow and harvest food (MIDNR 2017). Despite European settlement about 200 years ago, which resulted in many wetlands being drained and filled, wetlands remain a valued part of the culture of many tribes.

Less than half of pre-settlement wetlands in the United States remain. According to the National Wetland Condition Assessment of 2011, 32\% of the wetland area that remains nationally is in poor condition (USEPA 2016). Wetland loss occurred primarily through two avenues: conversion of wetlands to agricultural land and development due to population pressure and growth (Millennium Ecosystem Assessment 2005). When a wetland is drained or filled, the functions and services it was providing are lost.

In response to growing awareness of wetlands' importance and their historic loss, the United States Congress passed Section 404 of the Clean Water Act (CWA) into law in 1972 with the goal of no further loss of wetlands. Most wetland policy administrators use a process known as "full sequencing" or "mitigation sequencing" to protect wetlands. 
This involves avoidance of wetland impacts, followed by minimization of unavoidable impact, and lastly, mitigation of impacts through wetland creation or restoration (USEPA 2014). Although there is evidence that the first step, avoidance, is often skipped (Clare et al. 2011), wetland protection policy has significantly reduced the rate at which wetlands are lost (USEPA 2016). For example, from the 1950 s to the 1970 s, 458,000 acres of wetlands were lost per year on average (USEPA 2011). By 2009, the rate of wetland loss dropped to 13,800 acres per year (USEPA 2011). Despite the positive impact wetland protection policy has had on preserving wetlands, wetlands are still being lost. According to the National Oceanic and Atmospheric Administration and the U.S. Fish and Wildlife Service, over 360,000 acres of wetlands were lost in the conterminous U.S. between 2004 and 2009 (NOAA 2012).

There are also various state and local level wetland protection policies in place. Federal, state, and local level policies are implemented in different ways in different places. The Upper Great Lakes states, Michigan, Minnesota, and Wisconsin, each have their own wetland policies and implementation strategies at different levels of government. These states also have varying magnitudes of wetland area change at different scales, which can impact the benefits that wetlands provide. This thesis investigates the effectiveness of wetland policy design and implementation in protecting wetlands in the states of Michigan, Minnesota, and Wisconsin.

This thesis first aims to describe the extent of recent wetland loss in the Upper Great Lakes states and how it varies from county to county. Results show that more wetland loss occurred in Minnesota than in Michigan or Wisconsin between 2001 and 
2011 and that there was significant spatial variation in wetland loss among Minnesota counties. The purpose of this thesis is then to understand why wetland policy is failing in Minnesota.

A nested comparative analysis using Mill's Methods investigates wetland policy design at the state level (comparing Michigan-Minnesota-Wisconsin) and county-level policy implementation (within Minnesota) with outcomes of recent wetland area change. Ultimately, this thesis argues that Minnesota is experiencing a wetland policy failure due to issues in policy design. Results show that different state-level wetland policy designs and local-level implementation strategies can lead to differential impacts on wetland area. The combination of political pressure and limited oversight of local-level policy implementation may result in wetland loss, while true multi-agency involvement may mitigate wetland loss despite pressures from agriculture and development.

Understanding the type of failure that occurred and why it occurred is important, because it informs decision-makers on potential issues that interfere with goal achievement. The results show how policy design can impact the overall success of wetland policy goals, and suggest alternative routes for how less effective policies can be improved.

\section{Federal Wetland Policy}

The major federal policy, Section 404 of the Clean Water Act (CWA) of 1972, regulates disturbance and development of certain wetlands in all states. Section 404 of the CWA requires that a permit be obtained from the U.S. Army Corps of Engineers (USACE) for any non-exempt discharge of fill material into waters of the U.S. These 
waters include jurisdictional wetlands, which are those that are adjacent to navigable waters. Certain activities, such as farming activities, forest roads, and temporary sedimentation basins on construction sites, are exempt from these regulations, and therefore do not require a permit (USEPA 2014). Under section 404, environmental impacts on wetlands must be avoided if possible. Any unavoidable impacts must be minimized and mitigated to help achieve the national goal of "no net loss" of wetlands (USEPA 2014). Compensatory wetland mitigation is the restoration, creation, enhancement, or in certain cases preservation of a wetland to offset the adverse effects of the impacted wetland (USEPA 2014).

Mitigated wetlands often do not provide the same functions as the original wetlands impacted (Sheldon et al. 2005, Bendor 2009). One of the reasons for this is that it is difficult to recreate certain types of wetlands, such as wooded wetlands, bogs, and sedge fens (Sheldon et al. 2005). Also, mitigated wetlands are often in a different location, so the original location and the surrounding people are no longer benefitting from the wetland. A prominent issue with mitigated wetlands in distant locations is the impacts on watershed health (Sheldon et al. 2005, Kettlewell et al. 2008).

Mitigation banks are the preferred method of wetland mitigation for the USEPA and USACE because of the high rate of failure of independent wetland restoration and creation (USEPA 2014). If a wetland permit is approved, mitigation banks allow applicants to purchase wetland-banking credits in exchange for the wetland they impacted. Their success rate is higher than direct mitigation by applicants, because the created wetland must already be a success before credits are available to be used (USEPA 
2014). The credits come from wetlands that were created or restored by mitigation banks or existing wetlands permanently set aside prior to any wetland impacts. The USACE prefers that credits come from wetlands within the same watershed or county as the impacted wetlands, but such credits are not always available. In this case, independent wetland restoration or creation or mitigation banks from other counties can be used.

There are also several federal programs that incentivize conversion of agricultural lands back to wetlands. The Wetland Reserve Program offers payments to landowners who restore wetlands of 40 acres in size or more that have been altered by ditches or drain tiles. Local Natural Resource Conservation Service (NRCS) offices administer the program. The Partners for Fish and Wildlife Program administered by the USFWS assists landowners with wetland habitat restoration through cost shares and providing technical assistance (USFWS 2012). The Conservation Reserve Program authorized in the 2002 Federal Farm Bill uses incentives as a policy instrument if farmers remove cropped wetlands from crop production for periods of 10 to 15 years. While this program is primarily for grassland restoration, wetlands can also be restored. Local Farm Service Agency offices implement the program.

\section{Establishing Wetland Change in Michigan, Minnesota \& Wisconsin}

To establish an appropriate set of case study counties for this research, I first had to establish the extent of wetland change across the three case study states. The Upper Great Lakes states are interesting for studying wetland policy because of the importance of water and wetlands to the identity of the region from the surrounding Great Lakes and the abundance of inland lakes. These states are comparable in that they have similar 
demographics, culture, climate, and landscapes with similar amounts of wetland area. They also each have their own varied wetland policies in addition to Section 404 of the CWA, and they implement those policies differently.

First, wetland loss was calculated for Michigan, Minnesota, and Wisconsin at the county level using data from the National Land Cover Database (NLCD). NLCD data classify the landscape into 16 different land cover types at a 30-meter resolution across the U.S. It is publicly available, and provided in raster geodatabase format for use in ArcGIS. NLCD data are available for the years 2001 and 2011. NLCD data are a lower resolution than some other publicly available data. The National Wetlands Inventory has wetland data available in polygon shapefile format for ArcGIS at a scale of 1:24,000 to 1:25,000; however, the latest data available are from 2009. NLCD data were selected despite the low resolution, because they are available for a more recent year and in a simpler format for calculating area change over a large area.

The 2011 wetland area was calculated in ArcMap using the tabulate area tool for all wetland types by county. The process was repeated using 2001 data, and the 2001 results were subtracted from the 2011 results to get wetland area change by county. Wetlands are mostly being preserved at the state level, but there is still some loss in certain areas. Minnesota and Michigan both lost wetland area, and Wisconsin gained wetland area from 2001 to 2011 (Figure 1). Minnesota lost the most area, about 14,100 acres. Michigan lost about 3,600 acres, and Wisconsin gained over 2,000 acres statewide (NLCD 2001, NLCD 2011). 


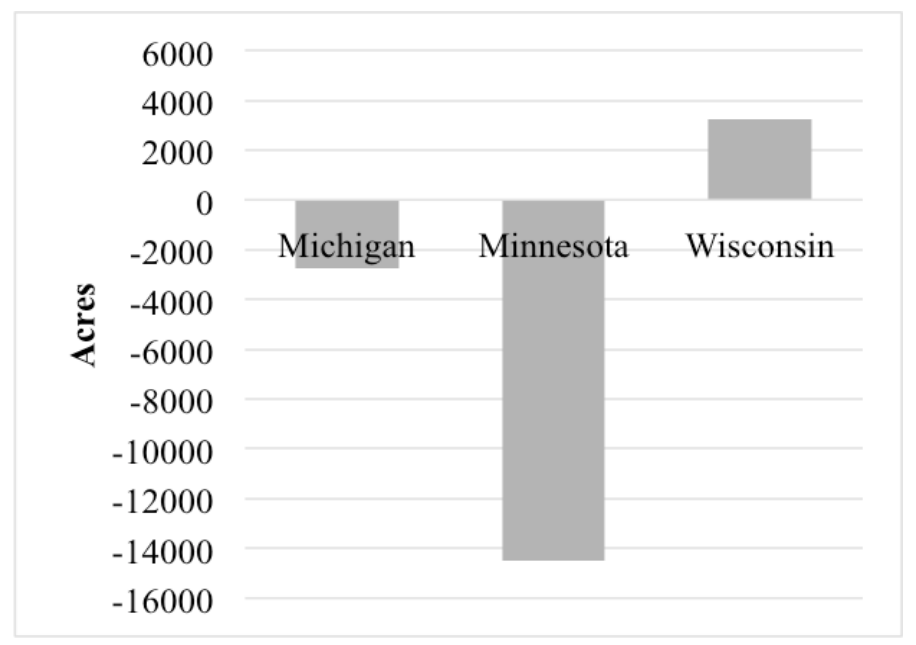

Figure 1. Change in Wetland Area 2001-2011

The greatest losses in wetland area are concentrated in Minnesota in the Minneapolis-St. Paul (MSP) metropolitan area and many of the surrounding agricultural counties, along with St. Croix County in northern Minnesota where the city of Duluth is located (Figure 2). The greatest gains in wetland area are in southwest Wisconsin and northern Minnesota. A Global Moran's I test of wetland area change across the three states at the county level using queen's case contiguity (neighbors are edges and corners) shows that there is significant spatial autocorrelation (Moran's $I=0.394, p<0.001$ ). This indicates that counties are similar to their neighbors with regards to wetland area change. 


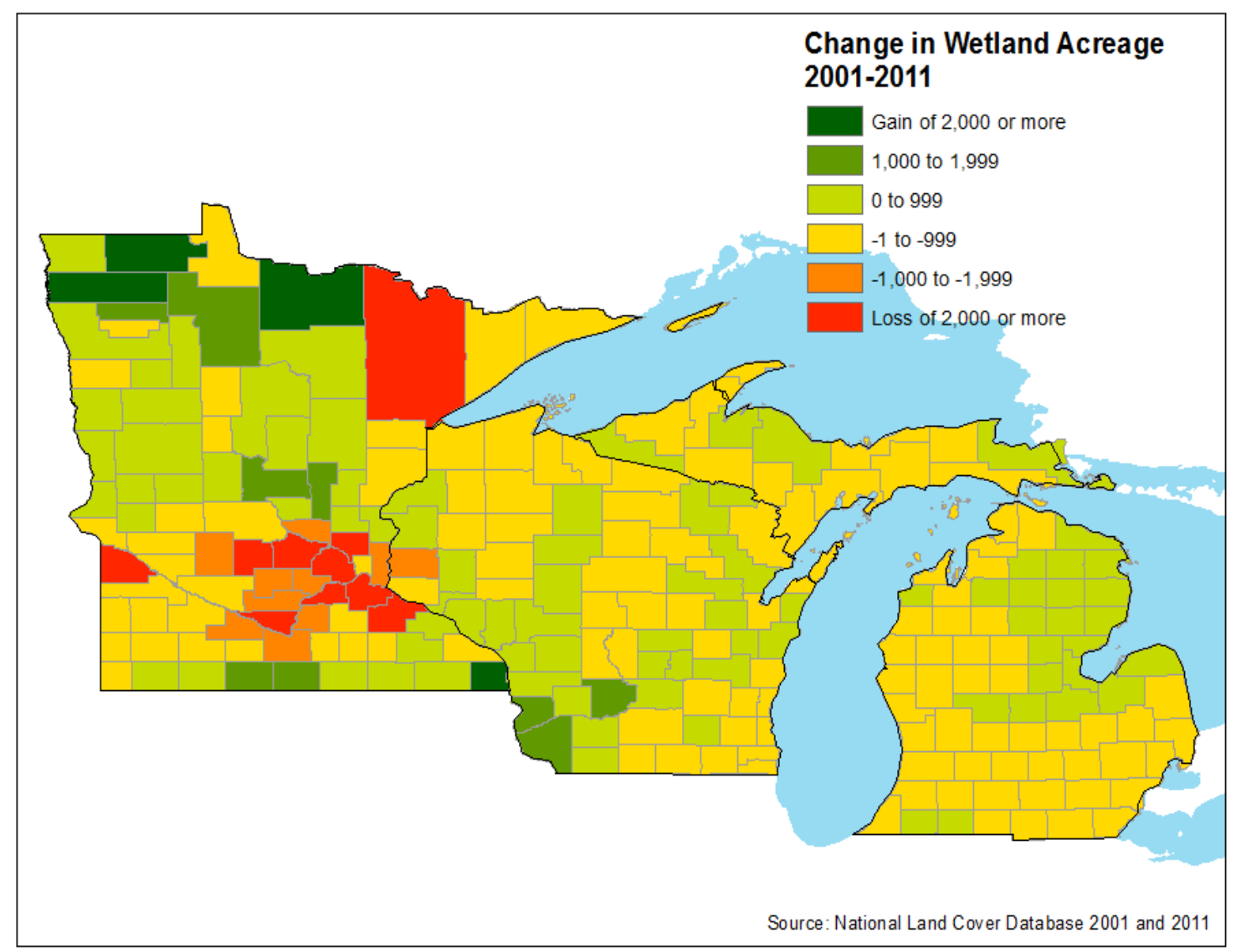

Figure 2. Change in Wetland Area by County 2001-2011

A Local Moran's I test of wetland area change for the same area shows that there are statistically significant $(p<0.05)$ high and low clusters of wetland change. This local indicator of spatial autocorrelation test shows where areas of statistically significant spatial autocorrelation are located. This test was also run using queen's case contiguity. There is a high-high cluster near the Minneapolis-St. Paul (MSP) metropolitan area of Minnesota; meaning counties with wetland loss are located near other counties with wetland loss in this area. There is also a low-low cluster in the rural northwest of Minnesota; meaning counties with wetland gain are located near other counties with wetland gain in this region (Figure 3). Wisconsin and Michigan do not have any clusters 
of statistically significant $(\mathrm{p}<0.05)$ spatial autocorrelation, indicating that there is little spatial variation in wetland loss at the county level in these states.

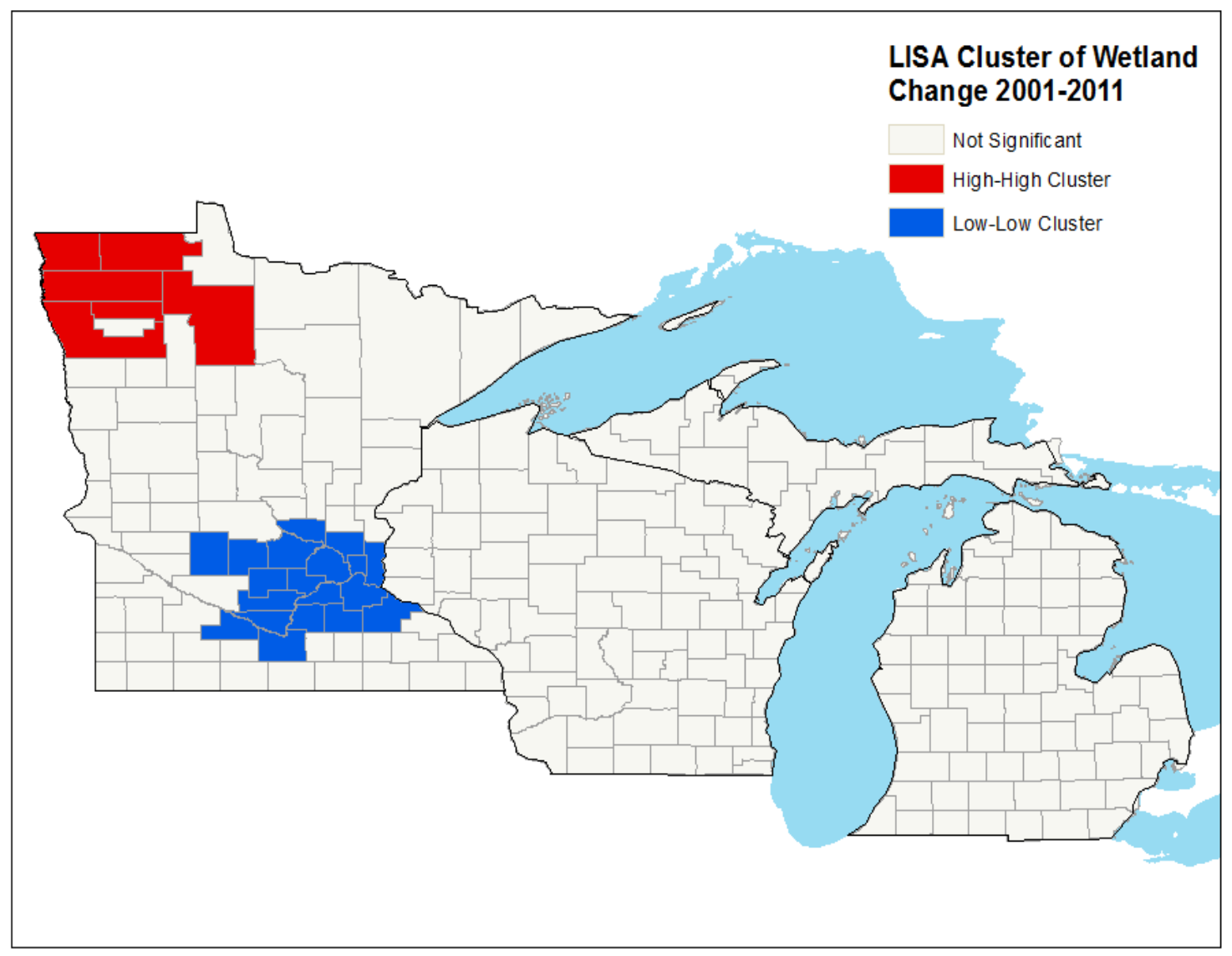

Figure 3. Moran's I test results for wetland area change across counties

The Global and Local Moran's I tests suggest that wetland area change in Wisconsin and Michigan is relatively homogeneous across counties in comparison with Minnesota, and there is a significant amount of county-level variation in wetland area change in Minnesota. A regression analysis (see Appendix B) determined that traditional explanations for wetland loss, both population pressure and agricultural pressure, had little explanatory power in predicting county-level wetland area change across the threestate region. Regime modeling suggested that relationships vary by state, and that both 
agriculture and population pressure could play a role in Minnesota. Altogether, the regression results fit poorly and suggest that something else (not captured in the models) is impacting wetland area change. At this point, I hypothesize that differences in the three states' wetland policies could explain the observed empirical differences in wetland area change across the three-state region.

Based on these observations, the primary focus of this study is on comparing policy design across states and policy implementation across counties in the greater MSP metropolitan area to determine why wetland policy is a failure in Minnesota.

\section{Literature Review}

McConnell (2010) defines policy success as a policy that "achieves the goals that proponents set out to achieve and attracts no criticism of any significance and/or support is virtually universal." (pg. 351) There are three components to this definition. To have policy success, first, goals that government sets out to achieve must be achieved. This is the simplest definition of a policy success. Second, policy will not be perceived as successful by everyone, meaning that even if someone views a policy as unsuccessful, that does not mean it is not a success. Third, subjective dimensions of success must be met, meaning that the policy must have support (McConnell 2010). Administrative implementation of routine non-controversial matters with low political conflict generally results in policy success (McConnell 2010). A wetland protection policy without support is a clear result of information failure. Contrary to McConnell's first and second components of his policy success definition, the federal wetland policy goal of "no net 
loss" could be perceived as successful, but if there is a net loss of wetland area, the policy is technically a failure.

McConnell (2010) expands his definition of policy success by describing policy success and failure as a spectrum. The spectrum allows for intermediate steps between policy success and failure to be differentiated. He divides policy success and failure of a program into five categories: program failure, precarious success, conflicted success, resilient success, and program success. Three of the components McConnell (2010) includes in this spectrum are the level that implementation aligns with objectives, the level of achievement of desired outcomes, and the level of support for program aims, values, and means of achieving them. When there are intermediate levels of goal achievement, support, and implementation of a policy, the level of success can fall somewhere between program success and program failure.

In this thesis, McConnell's definition of policy success is used to determine that wetland policy is failing in Minnesota, because the state and multiple counties are not achieving the goal of "no net loss." The focus is then on why wetland policy is a failure in Minnesota with emphasis on the importance of policy implementation.

\section{Policy Implementation Theory}

As McConnell included in his spectrum theory, policy implementation is critical for policy success. Implementation must align with policy objectives (McConnell 2010). There are three key elements of policy implementation: specification of program details, allocation of resources, and decisions (Fischer et al. 2007). "Specification of program details" includes how the law should be executed, which agencies should execute it, 
including who should oversee it, and how the law should be interpreted. "Allocation of resources" includes what personnel execute the law, what unit within an organization is in charge, and how the budget will be distributed, including resources set aside for oversight and evaluation. "Decisions" simply refers to how decisions are carried out for individual cases (Fischer et al. 2007). Issues and inconsistencies within any of these elements can cause policy implementation to fail. There are many ways to analyze these key elements of policy implementation.

Three traditional ways to implement policy are through a top-down approach, a bottom-up approach, or a hybrid of the two. There are strengths and weaknesses to both top-down and bottom-up approaches. The top-down approach is a hierarchical way of governance that generally starts with a policy decision by central government, such as through command-and-control regulations (Sabatier 1986). Some benefits of top-down policy implementation are clear policy goals and uniformity, but it does not allow for any significant local-level input (Fischer et al. 2007, deLeon and deLeon 2004). Policy formulation and policy implementation are treated as separate stages in policy making (Fischer et al. 2007). Bottom-up policy implementation starts with street level bureaucrats or local and state policy makers who make political decisions on implementation (Matland 1995). Local actors can then react to central government policy with their own program and implement it (Matland 1995). Policy formulation and policy implementation are not separate, as strategies are continually changing (Fischer et al. 2007, Sabatier 1986). 
Stoker (1991) expanded on the top-down versus bottom-up theory. He essentially labels these two approaches as 'authority' and 'exchange' respectively, but also adds a third alternative he labels 'governance.' Stoker views the governance approach as when reluctant partners are induced to collaborate on an activity (Hill \& Hupe 2014 pg. 68). He argues the importance of power to achieve collective goals rather than power over reluctant partners. This leads back to issues in policy design. When a policy is designed to allow for local-level alteration and partners are reluctant to implement policies, they may alter the policy to benefit themselves and/or powerful target populations (Schneider \& Ingram 1993).

Matland's ambiguity-conflict model is an alternative way to analyze policy implementation. Policy ambiguity can be caused by ambiguous policy goals or policy means used to achieve goals (Matland 1995). Greater ambiguity increases the role that local contextual factors play in policy implementation. For example, if the means used to implement a wetland policy are ambiguous, local officials can rank wetland protection with other goals. Depending on the local political environment, wetland protection may or may not be prioritized over other goals, such as economic growth. Policy ambiguity is seen as negative for top-down implementation, because it can cause uncertainty and misunderstanding, leading to policy failure. However, there are positive effects of ambiguity in that it can decrease conflict. Goal ambiguity and conflict are usually negatively correlated (Matland 1995). There can be policy conflict when a policy is relevant to two or more organizations with competing interests (Matland 1995). In topdown implementation, conflict is treated as a variable that can be minimized through 
proper policy design, whereas in bottom-up implementation, conflict is seen as dependent on the subject matter, but can be lessened through bargaining mechanisms (Matland 1995). Using incentives as a policy instrument for high conflict policies can minimize policy conflict to an extent (Matland 1995). For example, agricultural activities often conflict with wetland preservation. Providing monetary incentives for farmers who conserve wetlands or convert agricultural lands back to wetlands can minimize conflict between farmers and wetland policy decision-makers, and help to achieve policy success. Matland's ambiguity-conflict model in conjunction with Stoker's governance approach to policy implementation will be used to assess county-level implementation of Minnesota's Wetland Conservation Act.

\section{Wetland Policy Design and Implementation}

Whether local or centralized governance is better for wetland policy implementation and decision-making is still debated. Owens and Zimmerman (2013) argue that local decision-making for wetland policy is best in the case of Connecticut, because the decision-makers are close to the issues and the benefits. Similarly, Scholz and Wang (2006) argue that local water policy networks complement federal policy, improving compliance with the Clean Water Act. However, Alm and Witt (1997) claim that political pressure can play a key role in local decisions.

Alm and Witt (1997) argue that economic and cultural structures cause differences in social and political attitudes between urban and rural areas. They also argue that more economically diverse, urban communities tend to have greater support for environmentalism. When local elected officials make environmental decisions, 
decisions are highly dependent on the social, cultural, and political attitudes of the public and the elected officials themselves (Alm \& Witt 1997). This suggests that elected officials in urban communities are more likely to make pro-wetland protection decisions than elected officials in rural communities.

McBeth and Bennett (2001) claim that elected officials in both rural and urban communities generally do not support environmental regulations because they impeded on their primary goal of economic growth. This indicates that having elected officials making local wetland-permitting decisions could be problematic regardless of the societal, political, and economic status of the community. The decision-making structure for wetland permitting is, therefore, important to consider when assessing policy design.

Wetland policy has been found to fail when there are inconsistencies (Turner et al. 2010). One way policy can be inconsistent is through allowing local calibrations. When federal or state policies are designed to allow for local adjustments, the local political environment has more power over the policy. While local control is usually viewed positively, this thesis argues that with political pressure and limited oversight, it can be problematic.

Whether local-level wetland policy implementation is successful depends, in part, on monitoring, evaluation, and inter-agency oversight. Turner and Jones (2009) describe wetland policy intervention failure as when the absence of properly integrated resourcemanagement policies (at different levels of implementation) results in policy inconsistencies and negative wetland impacts. Institutional failures are intervention failures that can result in wetland loss due to a lack of monitoring and non-integrative 
agencies structure without effective oversight (Turner \& Jones 2009). Along with McConnell's definition of policy success, Turner and Jones' identified ways of how wetland policy can fail will be used to help determine why wetland policy is a failure in Minnesota. Their explanations of intervention and institutional failure help to explain issues in policy design, that lead to issues in implementation and oversight, and how these issues can be resolved.

Owens (2008) conducted a comparative analysis of policy implementation in wetland restorations in New Jersey, Oregon, The Netherlands, and Finland. Without oversight and evaluation, failed restorations and mitigations could go unnoticed and negatively impact wetland area and function (Owens 2008). Similarly, Clare and Creed (2014) found that $80 \%$ of wetland area loss in Alberta, Canada occurred without a permit, revealing significant issues with government oversight.

Overall, the literature suggests that the level of government at which the policies are implemented (local, state, or federal), who makes the decisions (with what level of political pressure), and how decisions are overseen can provide insight as to why Minnesota is losing wetland area.

\section{Population and Agriculture}

In addition to factors related to policy design and implementation, population and agricultural pressure have caused wetland loss (Millennium Ecosystem Service 2005). During colonial settlement, homesteaders drained wetlands to build houses and plant crops (Dahl \& Allord 1997). This trend continued through the 1950s when there was rapid population and industrial growth (Dahl \& Allord 1997). Wetland protection policies 
have slowed wetland loss significantly in recent years, but wetlands are still being affected by drainage and filling for agriculture and development (Millennium Ecosystem Assessment 2005, Dahl \& Allord 1997). The historical reputation between population and agricultural pressure and wetland loss calls for population and agricultural factors to be considered as potential causes for wetland change along with policy-related factors.

\section{Data \& Methods}

The analysis of wetland area change presented above suggests that policies are less successful at protecting wetlands in Minnesota than in either Michigan or Wisconsin and that a significant amount of local variation in wetland loss remains after considering obvious explanatory factors, such as population and agricultural pressure. Moving forward, comparative analysis is a useful tool to determine whether and how policy differences lead to these differential outcomes. Mill's methods were used in a two-stage nested comparative analysis:

1- to compare wetland policy design at the state level (comparing MichiganMinnesota-Wisconsin)

2- to compare local-level policy implementation practices and contextual factors to outcomes in recent wetland area change (in Minnesota).

The comparative method is an analysis of a small number of cases, including at least two observations, but not enough to use a conventional statistical analysis (Lijphart 1971). The comparative method is a weaker method for testing hypotheses than the experimental or statistical method because of the small $\mathrm{N}$ value, but it is stronger than using case studies (Lijphart 1971, Collier). The comparative method is arguably a better 
alternative to attempting the statistical method when the cases are limited. It is a way to look at cases as wholes and compare them as whole cases side-by-side (Lim 2010). To improve comparative analyses, the number of cases should be maximized, but only if they remain comparable, and variables can be reduced by combining related variables and using theory (Lijphart 1971, Collier 1991).

Mill's Methods of Difference, Agreement, and Concomitant Variation offer a way to analyze and interpret observations to help draw conclusions about the causal relationships they reveal. The state-level comparative analysis (Step 1) relies on Mill's Method of Difference, while the county-level analysis (Step 2) relies on the Methods of Difference, Agreement, and Concomitant Variation. Mill's Method of Difference is the argument that if there is an occurrence and a non-occurrence of the dependent variable, and the independent variables are the same in all circumstances except one, then that independent variable is the causal factor (Peters 1998, pg. 29). Using this method will help determine if state wetland policies are linked to state-level differences in wetland area change (Step 1). Mill's Method of Agreement is the argument that if multiple occurrences of the dependent variable only have one independent variable in common, then that independent variable is the causal factor (Peters 1998, pg. 29). Mill's Method of Concomitant Variation is the argument that if two variables vary in the same way, then they are linked either causally or through another variable (Peters 1998, pg. 29).

A key aspect of using Mill's Methods reliably is relevance. The independent variables must be relevant to the dependent variable. Mill's Methods cannot discover the 
cause unless the cause is already considered. This is a limitation of Mill's Methods, so it is important to make informed decisions on what to include in the analysis.

\section{Comparing Policy Design in Michigan, Minnesota, and Wisconsin}

Owens and Zimmerman (2013) and Scholz and Wang (2006) argue cases where local implementation of wetland policy was successful, but Alm and Witt (1997) and McBeth and Bennett (2001) suggest that political pressure plays a role in local wetland policy implementation, particularly when elected officials are responsible. This indicates that the level of implementation, local versus centralized, can be a critical factor in policy success or failure; therefore, levels of wetland policy implementation were included as the independent variable versus wetland loss in the state-level comparative analysis (Step 1). The level of government at which each wetland policy is implemented was uncovered by reviewing government documents for each policy. The policies were then divided between local, state, and federal implementation in the analysis to be compared side-byside with the overall wetland policy outcome for each state.

\section{Minnesota County Comparison}

Finding that Minnesota counties show significant variation in wetland area change and that in Minnesota wetland policy is designed to devolve more control to the local level than in either Michigan or Wisconsin (see more discussion on this finding in statelevel comparison results below), it is appropriate to compare wetland policy among Minnesota counties. The focus is on the MSP metropolitan area and surrounding counties within the high-high cluster uncovered by the Moran's I test, which indicated that these counties experienced significantly higher wetland loss than their neighbors. The county- 
level comparison was conducted in two steps. First, I conducted interviews with wetlands permit decision-makers in four case counties within the MSP metropolitan area. The interviews provide qualitative insight into which variables are important to consider in a broader comparative analysis (Step 2).

In an effort to uncover the most influential variables to use in the county-level comparative analysis for the region, four counties were selected in Minnesota to study wetland policy implementation from a qualitative perspective. Counties were selected in Minnesota, because the state-level comparative analysis (Step 1) suggested that locallevel policy implementation of the Wetland Conservation Act in Minnesota (and differences in the way decisions are made from county to county) might impact the extent of wetland loss. Interviews with four public officials involved in wetland permitting to learn about how wetland policy is implemented on the ground uncovered the pressures they face while making decisions regarding wetland permitting (see Interview Questions in Appendix A). The interviews, along with supporting studies, provided insight on variables to include in a county-level comparative analysis for the greater MSP metropolitan area in Minnesota.

The names of the counties selected for interviews remain anonymous in order to maintain confidentiality. These counties were selected based on a combination of the wetland change results, residuals from the regression analysis (Appendix B), results from the Moran's I test, and characteristics of each county. Moran's I test results show a statistically significant cluster of counties with high wetland area loss around the MSP metropolitan area, but some counties within this cluster have more loss than others. 
Between 2001 and 2011, of the four selected counties within the cluster, two counties experienced less loss in wetland acreage (about $-1,000$ acres each) than the other two counties (about -4,000 acres each). Two of these counties are within the seven-county planning region and two are outside the boundaries. The types of pressure (population or agriculture) the counties are under were also a factor in selecting these counties. One county is experiencing population pressure, another is experiencing agricultural pressure, and the other two are experiencing both population and agricultural pressure. Finally, the map of the residuals of the exploratory regression model (Appendix B) indicates that two of these counties saw more wetland loss than would have been predicted by global estimates of the impact of population and agricultural pressure and two saw less wetland loss than would have been predicted. This suggests that it could be local level policy differences impacting these outcomes.

In each of the four counties, a public official of the local government unit involved in making decisions on wetland permitting was interviewed. These four interviews took place over the phone, were audio-recorded, and transcribed. The public officials were asked questions about their job responsibilities, goals, and the competing pressures within wetland policy implementation (see Interview Questions in Appendix A). The interviews lasted about 30 minutes each. They were transcribed and analyzed for key themes that impact wetland-permitting processes in local-level implementation. Important themes that emerged from these interviews included: oversight, political pressure, and agricultural influence (see below for more discussion). These themes were then used as important factors in a county-level comparative analysis. 
In the second step, a comparative analysis of policy implementation practices and wetland area change was conducted using Mill's Methods of Comparison for 19 counties in southeast Minnesota located in the high wetland loss cluster (from the Moran's I test). A comparative analysis was used due to the low number of observations. The variables used in the county-level comparative analysis are outlined in Table 1. Change in wetland area from 2001-2011, as calculated using NLCD data, is the dependent variable. Evidence from the interviews and the studies by Owens (2008) and Clare and Creed (2014) suggest that limited oversight can have negative impacts on wetland policy success. The metropolitan status of each county, either inside the seven-county MSP metropolitan area or outside, is included as an indicator of oversight. Counties within the seven-county area are required to have Watershed Management Organizations (WMOs) that provide additional oversight on wetland-permitting decisions within the county. Alm and Witt (1997) and MacBeth and Bennett (2001) argue that local elected officials tend to prioritize economic concerns over the environment due to political pressure. Reviewing county websites and meeting minutes of conservation district and county board meetings uncovered the information on who the wetland-permitting decision-makers are in each county as a measure of political pressure.

Historical drivers of wetland loss - agricultural and population pressure - are also included as independent variables in the county-level comparative analysis. Percent agricultural land was calculated using data from the Agricultural Census 2010 as a measure of agricultural pressure. Population density, calculated from Census 2010 data, and change in housing units from Census 2000 and 2010 data were used as measures of 
population pressure. This comparative method will show what variables may be impacting wetland area at the county level in the greater MSP metropolitan area.

Table 1. Variables for county-level comparative analysis

\begin{tabular}{|c|c|c|}
\hline Data & Purpose & Data Source \\
\hline $\begin{array}{l}\text { Wetland Area Change } \\
\text { 2001-2011 }\end{array}$ & $\begin{array}{l}\text { Measures change in acreage to } \\
\text { determine extent of wetland loss at } \\
\text { the county level. }\end{array}$ & $\begin{array}{l}\text { Homer, C., Dewitz, J., Fry, J., Coan, M., Hossain, N., Larson, C., Herold, N., } \\
\text { McKerrow, A., VanDriel, J.N., and Wickham, J. 2007. Completion of the } 2001 \\
\text { National Land Cover Database for the Conterminous United States. Photogrammetric } \\
\text { Engineering and Remote Sensing, Vol. 73, No. 4, pp 337-341. } \\
\text { Homer, C.G., Dewitz, J.A., Yang, L., Jin, S., Danielson, P., Xian, G., Coulston, J., } \\
\text { Herold, N.D., Wickham, J.D., and Megown, K., 2015, Completion of the 2011 } \\
\text { National Land Cover Database for the conterminous United States-Representing a } \\
\text { decade of land cover change information. Photogrammetric Engineering and Remote } \\
\text { Sensing, v. } 81 \text {, no. 5, p. 345-354. }\end{array}$ \\
\hline Metropolitan Status 2010 & $\begin{array}{l}\text { Measure of oversight. Counties } \\
\text { within the seven-county metro area } \\
\text { have Watershed Management } \\
\text { Organizations for additional } \\
\text { oversight. Owens (2008) and Clare } \\
\text { and Creed (2014) suggest limited } \\
\text { oversight can cause wetland loss. }\end{array}$ & $\begin{array}{l}\text { Minnesota Board of Water \& Soil Resources. 2013. Overview of Watershed Districts } \\
\text { and Watershed Management Organizations. } \\
<\text { http://www.bwsr.state.mn.us/planning/WD-WMO_overview.html.> }\end{array}$ \\
\hline $\begin{array}{l}\text { Wetland-Permitting } \\
\text { Decision-Makers }\end{array}$ & $\begin{array}{l}\text { Proxy for political pressure. } \\
\text { McBeth \& Bennett (2001) and Alm } \\
\& \text { Witt (1997) indicate elected } \\
\text { boards experience greater political } \\
\text { pressure. }\end{array}$ & $\begin{array}{l}\text { Retrieved from interviews, county board meeting minutes, and conservation district } \\
\text { board meeting minutes. }\end{array}$ \\
\hline $\begin{array}{l}\text { Percent Land Area in } \\
\text { Agriculture/Farm } 2010\end{array}$ & $\begin{array}{l}\text { Measure of agricultural pressure, } \\
\text { assuming there is greater } \\
\text { agricultural influence in high } \\
\text { percentage counties. }\end{array}$ & $\begin{array}{l}\text { USDA NASS. 2007. Census of Agriculture, Quick Stats. } \\
<\text { https://quickstats.nass.usda.gov>. }\end{array}$ \\
\hline Population Density 2010 & $\begin{array}{l}\text { Proxy for population pressure in } \\
\text { conjunction with change in housing } \\
\text { units. }\end{array}$ & $\begin{array}{l}\text { United States Census Bureau / American FactFinder. "P1 : Total Population.” } 2010 \\
\text { Census.U.S. Census Bureau, 2010.<http://factfinder2.census.gov>. } \\
\text { United States Census Bureau / American FactFinder. "P2 : Urban and Rural." } 2010 \\
\text { Census.U.S. Census Bureau, 2010. <http://factfinder2.census.gov>. } \\
\text { USDA, Economic Research Service. } 2003 \text { Metro Classification using U.S. Census } \\
\text { Bureau, } 2010 \text { data. }\end{array}$ \\
\hline $\begin{array}{l}\text { Change in Housing Units } \\
2000-2010\end{array}$ & $\begin{array}{l}\text { Proxy for population pressure in } \\
\text { conjunction with population } \\
\text { density. }\end{array}$ & $\begin{array}{l}\text { United States Census Bureau / American FactFinder. "H1: Housing Units." } 2010 \\
\text { Census.U.S. Census Bureau, 2010. < http://factfinder2.census.gov>. } \\
\text { United States Census Bureau / American FactFinder. "H001 : Housing Units].” } 2000 \\
\text { Census.U.S. Census Bureau, 2000. <http://factfinder2.census.gov>. }\end{array}$ \\
\hline
\end{tabular}

\section{Results: State-level Comparison}

Wetland protection policies in Michigan, Minnesota, and Wisconsin are designed and implemented at multiple levels of government. The major federal policy is Section 404 of the Clean Water Act of 1972. The major state policy in Michigan is Part 303 of the Natural Resources and Environmental Protection Act of 1994. Minnesota has two major state policies: the Wetland Conservation Act of 1991 and the Department of Natural Resources Public Waters Work Permit Program of 1937. Wisconsin created a 
state permit system for wetland protection in 1991. Each of these state policies and policy instruments are discussed in the following sections.

\section{Michigan's Wetland Policies}

In all but two states, the federal Army Corps of Engineers (USACE) in conjunction with the U.S. Environmental Protection Agency (USEPA) administers the federal permit program. In New Jersey and Michigan, state departments administer the federal permit program. In Michigan, the state took control over the permit program in 1984 formerly under the Geomare-Anderson Wetland Protection Act. The Michigan Department of Environmental Quality (MDEQ) administers the permit program. The Michigan policy that takes the place of Section 404 of the CWA is Part 303 of the Natural Resources and Environmental Protection Act (NREPA), 1994 PA 451 on wetlands protection. Permits are used as a policy instrument and a requirement for depositing fill material or dredging a wetland, construction or development in certain wetlands, or draining surface water. The MDEQ administers Part 303 of the NREPA using regulations as a policy instrument to protect the following wetlands (MDEQ 2015):

- Connected to one of the Great Lakes or Lake St. Clair.

- $\quad$ Located within 1,000 feet of one of the Great Lakes or Lake St. Clair.

- $\quad$ Connected to an inland lake, pond, river, or stream.

- $\quad$ Located within 500 feet of an inland lake, pond, river or stream.

- Not connected to one of the Great Lakes or Lake St. Clair, or an inland lake, pond, stream, or river, but are more than 5 acres in size. 
- $\quad$ Not connected to one of the Great Lakes or Lake St. Clair, or an inland lake, pond, stream, or river, and less than 5 acres in size, but the DEQ has determined that these wetlands are essential to the preservation of the state's natural resources and has notified the property owner.

Mitigation is required for impacts to wetlands meeting the criteria. The NREPA put in place by the MDEQ currently does not require mitigation for what are labeled small, isolated wetlands. If a wetland is less than five acres in size and is not "contiguous", a permit is not required for destruction. Groundwater connections were not included in the definition of "contiguous" until Public Act 98 was instated in 2013. Prior to 2013, by Michigan regulation, wetlands were only considered "contiguous" if they had a surface water connection to other wetlands (USEPA 2014, Reyer et al. 2009).

Although the USEPA and USACE oversee the decisions made by the MDEQ, Michigan's wetland policy is primarily implemented at the state level.

\section{Minnesota's Wetland Policies}

Section 404 of the CWA is implemented by the USACE in Minnesota through the federal permit system. Minnesota has two other policies at the state level that directly impact wetlands: the Department of Natural Resources Public Waters Work Permit Program (MNDNR PWPP) and the Wetlands Conservation Act (WCA). After the WCA was enacted in 1991, implementation of wetland policy has been evolving in Minnesota. More wetland decisions have been made locally and regulatory duplication has made the permitting process more complicated for permit applicants and decision-makers. 
Under the MNDNR PWPP implemented by the MNDNR, a work permit is required for any activities that affect the "course, current, or cross-section of public waters, including public waters wetlands" (MNDNR 2015). Public waters wetlands are those defined as type 3, 4, or 5 by the U.S. Fish and Wildlife Service (USFWS). This leaves out wetlands less than ten acres in size in unincorporated areas and those less than $2-1 / 2$ acres in size in incorporated areas.

Minnesota's Wetland Conservation Act (WCA) of 1991 protects all wetlands that are not protected by the DNR's PWPP to help achieve the national goal of "no net loss". Any wetlands that are drained or filled must be replaced by mitigation, either by restoring or creating new wetlands of equal public value as those destroyed. Local government units implement the WCA, and are overseen by the Minnesota Board of Water and Soil Resources (MN BWSR 2015). If a wetland is regulated under the WCA, the requirement of a permit through the PWPP for projects within public waters wetlands can be waived as of the year 2000 unless the wetland is under shoreland classification, lacustrine, or deep-water habitat. Exemptions of the WCA include certain agricultural activities, maintenance of existing public and private drainage systems, public utilities, and public road maintenance (MN BWSR 2015). To simplify the application process, the USACE and MN BWSR began utilizing a joint application form in 2007 for activities affecting water resources in Minnesota. The same form can then be sent to the USACE for Section 404 of the CWA, and to local government units for the WCA. The form has since been revamped and is still being streamlined for inclusion of the MNDNR's PWPP. 
Minnesota also has the Reinvest in Minnesota Reserve Program that began in 1986 and was formerly administered by the BWSR. Landowners received payment to voluntarily enroll environmentally sensitive agricultural lands in a conservation easement by restoring wetlands. The Reinvest in Minnesota Reserve Program now partners with the federal Wetland Reserve Program, and is administered by local Soil and Water Conservation Districts.

While some of the larger wetlands in Minnesota are protected by at the state level through the MNDNR's PWPP, most are under the jurisdiction of the locally implemented WCA with oversight from the USACE. Minnesota has wetland policies implemented at the local, state, and federal levels, but most inquiries and decisions are initially made locally.

\section{Wisconsin's Wetland Policies}

Section 404 of the CWA is implemented by the USACE in Wisconsin through the federal permit system. Beyond Section 404 of the CWA, the state of Wisconsin has a separate permit system implemented by the Wisconsin DNR as part of their wetland regulatory program. The state program was created in conjunction with the USACE and is based on Section 404 of the CWA for water quality standards (2008). General permits are available for discharges up to 10,000 square feet in wetlands from industrial, commercial, and residential development, or individual permits can be used for any wetland disturbance activities where general permits are not available. Compensatory wetland mitigation is required for individual permits. The major differences between the Wisconsin and federal wetland policies are that Wisconsin regulates construction 
activities in all wetlands, including isolated wetlands. Also, wetland mitigation is not required for all wetland fills under Wisconsin regulation, whereas mitigation is required for all wetlands that fall under the requirements of federal regulation (WWA 2002).

The WIDNR has funds for wetland restoration in priority areas for waterfowl habitat. Funding is raised by waterfowl hunting license sales and federal grants. The Wisconsin Waterfowl Association also provides funding and assistance for waterfowl habitat restoration through partnerships and cooperatives, among many other state and local level programs that help to protect wetland habitat and other ecological functions in Michigan, Minnesota, and Wisconsin.

Wetland policy in Wisconsin is implemented at the state-level by the WIDNR and the federal level by the USACE. Since the state permit system was created to be in line with the Section 404 of the CWA, applicants generally go to the WIDNR for approval before the USACE.

\section{Summary and Comparison for Three States' Wetland Policies}

The state-level differences in wetland protection policies as well as the agency responsible for implementation are summarized in Table 2. 
Table 2. Summary of state and federal wetland policies

\begin{tabular}{|c|c|c|c|}
\hline State & Policy & Wetlands Protected & Implementation \\
\hline \multirow[t]{6}{*}{ Michigan } & \multirow{6}{*}{$\begin{array}{l}\text { Part } 303 \text { Natural } \\
\text { Resources and } \\
\text { Environmental } \\
\text { Protection Act }\end{array}$} & Connected to a Great Lake & \multirow{6}{*}{$\begin{array}{l}\text { State of MI DEQ assumes } \\
\text { federal weland permitting } \\
\text { authority }\end{array}$} \\
\hline & & Less than 1000' from a Great Lake & \\
\hline & & Less than 500' from an inland lake, pond, river, or stream & \\
\hline & & Connected (contiguous) to an inland lake, pond, river, or stream & \\
\hline & & Not connected, but greater that 5 acres in size & \\
\hline & & $<5$ acres, DEQ claims essential for natural resource preservation & \\
\hline \multirow[t]{4}{*}{ Minnesota } & \multirow{3}{*}{$\begin{array}{l}\text { DNR Public Waters } \\
\text { Work Permit Program }\end{array}$} & Work affecting the course, current, or cross section of public waters & \multirow[t]{3}{*}{ MN DNR } \\
\hline & & $>10$ acres in unincorporated areas & \\
\hline & & $>2.5$ acres in incorporated areas & \\
\hline & $\begin{array}{l}\text { Wetlands } \\
\text { Conservation Act }\end{array}$ & All wetlands not protected under DNR's PWPP & Local Government Units \\
\hline Wisconsin & State Permit System & ALL wetlands, including "isolated" (not covered by federal laws) & WI DNR \\
\hline All states & $\begin{array}{l}\text { Section } 404 \text { of the } \\
\text { Clean Water Act }\end{array}$ & Adjacent to or have a hydrologic connection to navigable water ways & Army Corp of Engineers \\
\hline
\end{tabular}

At the state level, Minnesota may be losing more wetlands than Wisconsin and Michigan primarily because of the differences in wetland policy design and implementation. Michigan has the DEQ administering Section 404 of the CWA. This is state-level implementation. The DEQ does not have elected officials, therefore their decisions are not as influenced by politics, specifically the local political environment. Wisconsin has the U.S. Army Corps of Engineers (USACE) implementing Section 404 of the CWA and the DNR implementing the state permit system. USACE and DNR officials are also not elected. Evidence suggests the USACE is more involved in the permitting process in Wisconsin than in Minnesota, because Wisconsin does not have a state law comparable to Minnesota's WCA to provide wetland protection.

Minnesota has the USACE implementing Section 404 of the CWA, but each official from the USACE covers a large area of about 25 counties. Minnesota also has the Public Waters Work Permit Program implemented by the DNR, but the WCA is likely the most influential in wetland area change, because any proposed impacts to wetlands that are not protected by the PWPP are then assessed under the requirements of the WCA. 
The WCA is designed so that decisions about permitting procedures are made at the local level, meaning the three key elements of policy implementation, specification of program details, allocation of resources, and decisions (Fischer et al. 2007), are determined at the local level. This leaves the law up for interpretation by local, sometimes elected, officials who can determine if wetland permitting should be a political or administrative decision. The literature suggests that elected officials may be against environmental regulation, particular those who are in rural communities. If elected officials are responsible for making local-level wetland-permitting decisions, policies with local implementation may not be protecting wetlands as well as others.

A state-level comparison determines what factor might be causing wetland loss and policy failure in Minnesota. The state-level comparative analysis compares wetland policy outcome in the three states, Michigan, Minnesota, and Wisconsin, with the level of implementation for their wetland policies (Table 3).

Table 3. Selected characteristics of wetland policies in the three-state region

\begin{tabular}{|c|c|c|c|c|}
\hline State & $\begin{array}{c}\text { Local-level } \\
\text { Implementation }\end{array}$ & $\begin{array}{c}\text { State Agency } \\
\text { Implementation }\end{array}$ & $\begin{array}{c}\text { Federal Agency } \\
\text { Implementation }\end{array}$ & Policy Outcome \\
\hline Michigan & No & Yes & No & Success \\
\hline Minnesota & Yes & Yes & Yes & Failure \\
\hline Wisconsin & No & Yes & Yes & Success \\
\hline
\end{tabular}

Using Mill's Method of Difference, there is an occurrence and a non-occurrence of the dependent variable; there is policy failure in Minnesota, but not in Michigan or Wisconsin. Also, the independent variable, local-level implementation, is the same in all circumstances except one; Minnesota has local-level policy implementation, while Michigan and Wisconsin do not. This indicates that Minnesota's local-level policy, the 
Wetland Conservation Act (WCA), may be the causal factor for wetland loss. This led to the county-level comparative analysis for the greater MSP metropolitan area to further examine the relationship between the WCA and wetland loss in Minnesota.

\section{Minnesota County Interviews}

Minnesota's WCA policy is different from other state policies in that it starts with local government units. For the WCA, each county decides on the strategy they will use to make permitting decisions, causing the policy implementation process for wetland replacement plan applications to vary from county to county. There are three primary ways that final decisions for wetland permitting are made under the WCA (Ken Powell, WCA Operations Coordinator, personal communication, February 14, 2017):

1- An elected or appointed governing board, such as a County Board of Commissioners or City Council, can make decisions during public meetings.

2- The governing board can delegate some or all decisions to staff.

3- The governing board can delegate decisions to another governing board.

Of the four counties where a wetland-permitting official was interviewed to help uncover variables to include in the county-level comparative analysis, two counties are in the seven-county planning region, and two are outside. Of the two counties in the sevencounty planning region, one uses an elected board to makes final permitting decisions, and the other uses staff. Similarly, of the two counties outside the seven-county planning region, one uses an elected board and the other uses staff. Three factors of interest that may be impacting wetland area in the greater MSP metropolitan area in Minnesota were uncovered through the interview process: agriculture, limited oversight, and political 
pressure. The key factors and their relationships with wetland loss uncovered by the interviews are included in Table 4.

Table 4. Summary of Key Factors from Interviews

\begin{tabular}{|r|c|c|c|c|c|c|}
\hline County & $\begin{array}{c}\text { MSP } \\
\text { Oversight }\end{array}$ & $\begin{array}{c}\text { Population } \\
\text { Pressure }\end{array}$ & $\begin{array}{c}\text { Agricultural } \\
\text { Pressure }\end{array}$ & $\begin{array}{c}\text { Political } \\
\text { Pressure }\end{array}$ & $\begin{array}{c}\text { Decision-making } \\
\text { Structure }\end{array}$ & $\begin{array}{c}\text { Extent of } \\
\text { Wetland Loss }\end{array}$ \\
\hline 1 & Yes & High & Low & High & Elected Board & Low \\
\hline 2 & Yes & Mid & Mid & Low & Staff of Specialists & Low \\
\hline 3 & No & Low & High & High & Staff (Other) & High \\
\hline 4 & No & High & Mid & High & Elected Board & High \\
\hline
\end{tabular}

Agriculture

One factor of interest derived from the interviews is agriculture. The interviews suggest agriculture is linked to wetland loss. One county seeing minimal wetland loss does not have many farmers applying for wetland permits, because farmers are not expanding their production area. A wetland manager of this county stated, "We are losing more (agricultural land) than expanding due to development, but not as much as we thought we would. When the market crashed that trend shifted, so we're not losing as much as we were." This shows that population and development pressure are much stronger than agricultural pressure in this county. This county has an elected board that makes final permitting decisions, but does not have pressure from the agriculture and farming community.

A county seeing significant wetland losses is being impacted by farming and agriculture. A specialist involved in wetland permitting in this county stated, "Sometimes you hear that farmers are overregulated. They aren't allowed to do something because of regulation. With the law that I am administering, the state WCA, there are numerous exemptions that were specifically written in to exempt a lot of farming practices...the 
exemptions that exist are in conflict with the overarching goal of the law." This indicates that the exemptions of the law itself work against policy goals, so the design of the policy is in conflict with policy goals.

When asked if they get farmers looking for wetland permits, a specialist in a county seeing significant loss stated, "Not as many as I should get compared to the activity I see going on. I should be getting more formal permits. The system is set up in a way where they are not required to come through our door to get a permit." This shows that farmers are not always required to obtain a permit when they impact wetlands, further exacerbating the negative effects that agriculture can have on wetland area.

A wetland permitter in another county seeing more wetland loss stated, "Most landowners in the rural area will tell you that these wetland areas are more of a nuisance than a benefit because they affect their cropping systems." This statement shows that there is clearly an anti-environmental sentiment in local rural areas that may cause political pressure for wetland decisions. This, along with the evidence suggesting that the agricultural community has political power, indicates that agriculture is causing wetland loss in this county.

One of the major target populations for wetland policy is the agricultural community. As one of the biggest drivers of wetland loss historically, agricultural practices are often burdened by wetlands, and thus many proposed wetland impacts are related to agriculture. Agriculture is an important aspect to many communities, both culturally and economically. Since agriculture is a large business often involving a lot of local residents, elected officials are likely to consider concerns from the agricultural 
community when dealing with wetland policies. Therefore, agricultural counties may experience more wetland loss. This reasoning in conjunction with findings from the interviews concludes why percent agricultural land from the agriculture census (2010) was included in the county-level comparative analysis.

\section{Limited Oversight}

Another factor of interest derived from the interviews is limited oversight. While some counties have more oversight on wetland-permitting decisions than others, there is evidence that it is an issue in some counties. Although wetland-permitting decisions are overseen by the Army Corps of Engineers, the USACE is "understaffed and overworked" in Minnesota according to specialists in the two counties with more wetland loss, so the USACE is minimally involved. Each USACE office covers a very large area. As stated by one interviewee, "If I did not notify (The USACE) of projects, they would have no idea what was happening out in the land...they don't have time to go out and be present locally." The USACE may assume, as suggested by an interviewed public official, that local government units implementing the WCA at the city, township, and county levels are providing enough regulation on wetland issues that the USACE does not need as many resources in Minnesota.

Farmers receive less oversight than others when performing activities in and around wetlands due to exemptions. One of the exempt activities is tile maintenance. If a farmer needs to repair or replace a tile, they are not required to obtain a permit, but they can gain approval from the Farm Service Agency (FSA). According to a specialist from a county with significant wetland loss, there is little incentive to gain approval. After a 
farmer is approved by the FSA to repair or replace a tile, as stated by the specialist involved in wetland permitting, "There is no follow up. No one goes in the field. No one surveys anything. No one verifies whether that tile is larger than what was there before or if it even existed in the first place. It's going rampant all across the state." According to the specialist, there is evidence of this. The official stated, "I'm seeing a lot of agricultural drainage. There is a lot of tiling. There is a lot of ditching. There is a lot of drainage that's going on and it is not being watched closely by the NRCS." The absence of monitoring for tile maintenance leaves farmers on the "honor system" to go through the process of obtaining a permit if they plan to install a larger tile or an additional one. This indicates that a relationship between wetland loss and a combination of limited oversight and agriculture is something to look for in the county-level comparative analysis.

Counties within the seven-county planning region each have their own Watershed Management Organization. Watershed Management Organizations are mandatory for the seven-county planning region, requiring local government units to create and implement surface water management plans. This provides more oversight for all wetlands with surface water within the seven-county planning region. Additional oversight would be expected to reduce wetland loss, so metropolitan status was also included as a variable in the county-level comparative analysis.

\section{Political Pressure}

Political pressure is another factor of interest from the interviews that may be associated with wetland loss. A specialist who implements the WCA in a county seeing 
minimal wetland loss explained that there are no conflicting goals within the specialist's job, because the department is not set up that way. The specialist stated, "In my role in permitting my focus is limited to storm-water management and wetland conservation, so the way things are structured in my county sort of minimizes conflicts.” The primary purpose of this specialist's job is to implement the WCA, and decisions are made in conjunction with other agencies, including the Conservation District and the Board of Water and Soil Resources. This indicates that there is little political pressure in this particular county.

There is clearly some political pressure in certain counties when elected boards make wetland-permitting decisions. A specialist of a county seeing significant wetland loss stated, "Regulation takes a lot of backing. You need to have support from people locally. Like I said I've had pressures from county commissioners to defund us partially." This indicates that some county commissioners have views or are under pressures that they value more highly than wetlands. Wetland-permitting decision-makers are not only pressured by the local community in this county, but also by people positions of power. When this is the case and there is flexibility in the decision process of policy implementation, wetlands are likely to be lost.

A specialist of a county seeing more wetland loss stated, "If there is some local political pressure or something else outside the law, the board could go against our recommendation and issue an approval despite our recommendation. That wiggle room or flexibility does exist within the system." This is a clear difference between the WCA and Section 404 of the CWA, as decisions made under the WCA can be political decisions 
and decisions made under Section 404 of the CWA are administrative. This gives reluctant officials the ability to ignore the goals of wetland policy in favor of other goals.

During a specific case that was presented to an elected board for a final decision, it was clear that local pressure played a role. This took place in a county seeing significant wetland loss. The case started as a staff decision that the applicant was not exempt. It was then appealed and brought before the board. The specialist stated, "One of our board members knew the applicant, so right there you've got this immediate connection, kind of a conflict of interest, so there's that that was playing out." The case resulted in a wetland being drained with no mitigation required. When local officials are implementing a policy, they are more likely to personally know the people the policy affects, and may feel more pressure for the outcome of a decision to be in their favor. This issue is compounded when the official is elected, and feels the need to help out their neighbors in order to get reelected. Another wetland permitter of a county with more wetland loss stated, "Neighbors have a right to comment on permits. That weighs into consideration. They could negatively affect their neighbors' quality of life." This shows that this wetland permitter also takes concerns outside of the WCA into consideration when making decisions.

Using Matland's ambiguity-conflict model, it is more likely to have greater ambiguity in wetland policy implemented at the local level and when decisions are more political than administrative. When decisions are political, there is bargaining between groups and organizations and more flexibility in making decisions. There is higher conflict when there are opposing views, or in this context, when there are individuals 
involved who do not value wetlands as highly as other land uses. This sort of conflict may be particularly influential when decisions are political. In this recognition, high ambiguity and high conflict policy implementation may lead to wetland loss, so it would be expected in counties where permitting decisions are more political than administrative to see more wetland loss. The wetland-permitting decision-maker, elected board (political) versus staff (administrative), was included as a variable in the county-level comparative analysis for this reason and based on evidence from the interviews.

\section{Minnesota County-level Comparison}

Comparing counties in the greater MSP metropolitan area will allow us to see what is causing wetland loss in some counties more than others. Results of the countylevel comparative analysis of all counties in the wetland loss cluster (from Moran's I test) in Minnesota are shown in Table 5. All of these counties are in or surrounding the MSP metropolitan area. The requirement of a Watershed Management Organization (WMO) for all counties in the seven-county MSP planning region provides additional oversight for wetland-permitting decisions. Counties outside the seven-county MSP planning region do not have this additional oversight. The table is organized first by WMO oversight status and second by wetland loss for each county to highlight the differences in relationships between other variables and wetland loss by WMO oversight status. 
Table 5. Selected characteristic of counties in the greater MSP metropolitan area

\begin{tabular}{|l|c|c|c|c|c|}
\hline County & $\begin{array}{c}\text { WMO } \\
\text { Oversight }\end{array}$ & Political Pressure & $\begin{array}{c}\text { Agricultural } \\
\text { Pressure }\end{array}$ & $\begin{array}{c}\text { Population } \\
\text { Pressure }\end{array}$ & $\begin{array}{c}\text { Extent of } \\
\text { Wetland Loss }\end{array}$ \\
\hline Ramsey & Yes & Elected Board & Low & High & Very Low \\
\hline Washington & Yes & Elected Board & Low & High & Low \\
\hline Carver & Yes & Staff of Specialists & Mid & Mid & Low \\
\hline Scott & Yes & Staff of Specialists & Mid & High & Mid \\
\hline Dakota & Yes & Staff of Specialists & Mid & High & Mid \\
\hline Hennepin & Yes & Staff of Specialists & Low & High & High \\
\hline Anoka & Yes & Elected Board & Low & High & High \\
\hline Rice & No & Staff of Specialists & Mid & Mid & Low \\
\hline McLeod & No & Staff of Specialists & High & Low & Low \\
\hline Blue Earth & No & Staff of Specialists & High & Mid & Low \\
\hline Sibley & No & Staff of Specialists & High & Low & Low \\
\hline Le Sueur & No & Staff of Specialists & High & Low & Low \\
\hline Sherburne & No & Staff of Specialists & Low & Mid & Low \\
\hline Kandiyohi & No & Elected Board & High & Low & Mid \\
\hline Brown & No & Elected Board & High & Low & Mid \\
\hline Meeker & No & Two Staffs & High & Low & Mid \\
\hline Goodhue & No & Single Staff Member & High & Low & High \\
\hline Wright & No & Elected Board & Mid & Mid & Very High \\
\hline Nicollet & No & Two Staffs & High & Low & Very High \\
\hline
\end{tabular}

Using logical comparison, if a county does not have WMO oversight and if a county has an elected board that makes wetland-permitting decisions, the county experienced higher wetland loss. According to the county-level comparative analysis, whether the county has Watershed Management Organization (WMO) oversight determines the way other variables impact wetland loss. Counties within the sevencounty MSP planning region have WMO oversight and clearly have different relationships with variables than counties without WMO oversight. Despite the significant population and development pressure in some of the seven counties, there are still counties outside the seven-county planning region with greater wetland loss. Within 
the seven-county MSP planning region, counties with high population density and greater change in housing units experienced more wetland loss. Note that wetland loss in Ramsey County may be low in part due to the small size of the county compared to others in the region.

The analysis also shows that having elected boards as wetland-permitting decision-makers for the WCA can cause wetland loss for counties without WMO oversight. Political pressure is a greater issue when elected boards make wetlandpermitting decisions, as elected boards typically embody the views of their community. Counties with one staff of specialists who make wetland-permitting decisions experienced less loss than counties with other groups making decisions (elected boards, multiple staffs, and single staff member) outside the seven-county MSP planning region. Evidence suggests that the process of using multiple staffs, where one staff makes decisions on agriculture related activities and another staff makes decisions for other activities, might be problematic. These staffs then have to communicate back and forth to ensure all projects are watched and all violations are investigated. Having a single staff member might also be less desirable than a full staff for permitting decisions, as there is no one at the same level to either back up or challenge decisions.

Population and agriculture are not as clearly related to wetland area change as the policy structures. Counties outside the seven-county MSP planning region have less population and development pressure, and more agriculture. While counties with the most wetland loss outside the seven-county MSP planning region have high agricultural 
area, there are similar counties with less wetland loss, so the relationship between agriculture and wetland loss in not clear from the comparative analysis.

\section{Discussion}

Comparative analyses at the state- and county-level demonstrate that there are significant differences in wetland policy implementation practices of the WCA between counties in Minnesota, and these differences have implications for wetlands. When elected boards make wetland-permitting decisions, particularly in agriculturally dominant areas, political pressure may make the policy less effective. The results suggest that designing wetland policies for multi-agency involvement and the use of policy instruments, such as financial incentives, at the local level, may ameliorate impacts of political pressure. With true multi-agency involvement, there are more resources and oversight to ensure policy execution, and thus, policy success.

Local political pressure and limited oversight are contributing to wetland loss in some counties in Minnesota. Local political pressure does not influence permitting decisions in Wisconsin and Michigan as much as in some counties in Minnesota, because specialists at higher levels of government make the decisions in Wisconsin and Michigan. There is ambiguity in Minnesota wetland policy design, because policy means for implementing the WCA are determined by local government units. There is arguably greater local conflict in Minnesota as well, particularly in agricultural counties with local elected officials as decision-makers rather than specialists. This supports the conclusions by Alm and Witt (1997) and MacBeth and Bennett (2001) that local elected officials tend 
to prioritize economic concerns over the environment, particularly within rural communities where local natural resources are used as a commodity.

The results indicate that wetland policy is an intervention and institutional failure in Minnesota, because the wetland policies are not properly integrated, resulting in policy inconsistencies across counties and negative wetland impacts. It is a failure because of the design of the Wetland Conservation Act and its local level implementation. There is also insufficient monitoring in places, particularly outside the seven-county MSP planning region.

The results demonstrate that removing political pressure from decision-making can improve the success of local level regulation. Elected boards are more likely to consider factors outside of environmental policy, making decisions political, whereas staff decisions are more administrative. Flexibility in policy design, such as allowing the decision-making process to be determined at the local level, leads to these potential issues in implementation.

In places where communities have political pressure or an anti-environmental sentiment, carrying out environmental policies can cause political strife between elected officials and the community. Elected officials may then choose to modify or compromise in their decisions to ameliorate conflict. In wetland policy, local political pressure and goals for economic growth may lead local elected officials to approve wetland permits and exemptions that would have been denied if determinations were made solely using the wetland policies. Noncompliance with the federal law, Section 404 of the CWA, may 
then occur, possibly unnoticed or appealed too late by the short-staffed USACE, ultimately resulting in a loss in wetland area.

While wetland policy is rarely implemented purely through a single theoretical approach, policies are generally implemented in a way more similar to one approach than others. Stoker's implementation theory defines the governance approach as an activity that reluctant partners are induced to collaborate on (Stoker 1991). Implementation is a governance approach in certain counties in Minnesota, because evidence from interviews suggests some local-level officials involved in wetland permitting are doing so reluctantly. They are the main policy actors involved in the negotiation processes used in implementation in some counties. When reluctant partners, elected officials or staff, have the ability to alter a policy locally, they can change it to benefit the goals of their local community or themselves, possibly causing environmental degradation.

\section{Conclusions}

Despite the federal policy of "no net loss" of wetlands, there is still wetland loss in some areas. This research shows that some wetland policy implementation practices are not as effective as others in protecting wetlands. Political pressure and limited oversight can contribute to wetland loss. Elected board members making final permitting decisions can have more conflicts of interest, causing wetland loss, than when a staff of specialists makes final decisions. True multi-agency involvement by policy design could provide more oversight ensuring compliance with federal, state, and regional policies, simplify the regulatory process for applicants, and ultimately may be more effective at combatting wetland loss. 
This research could be expanded by conducting more interviews at varying levels of government in Minnesota and in different states. The small number of interviews conducted is a limitation of this study. An in-depth analysis of more counties in Minnesota would improve the analysis. The low number of observations in the countylevel comparative analysis is also a limitation $(n=19)$. With more observations, a statistical regression analysis could be used. This would require quantifiable policy implementation data at the county-level. The resolution of the wetland data from the NLCD is also a limitation of this study. Higher resolution data would allow wetland change to be assessed at finer scales than the county level.

As stated by deLeon and deLeon (2004), the key to successful policy implementation is good policy evaluation. While there may be essentially "no net loss" of wetland area at larger scales, there are losses at the county level. When wetland policies are evaluated at the county level, we see where wetland policy implementation is working and where it is falling short. This paper demonstrates the importance of sub-state analysis in wetland policy evaluation.

We are also able to give suggestions for improvements at the local level. This research shows that limited oversight in local-level policy implementation can be problematic, as permits and exemptions can be granted at the local level that do not comply with federal policy. Having an elected board in charge of making wetlandpermitting decisions can also be problematic, as political pressure can ultimately result in wetland loss. The consequences may be magnified in agricultural areas by pressure from farmers and by nonexempt farming activities being treated as exempt due to insufficient 
monitoring. Minnesota may improve their wetland protection with more oversight by the USACE or a state agency, such as the BWSR, on compliance with Section 404 of the CWA, and better use of policy instruments at the local level. 


\section{References}

Alm, L.R. \& Witt S. 1997. The rural urban linkage to environmental policymaking in the American West: A focus on Idaho. The Social Science Journal, 34(3): 271-284.

Bendor, T. 2009. A dynamic analysis of the wetland mitigation process and its effects on no net loss policy. Landscape and Urban Planning, 89(1-2): 17-27.

Burns, R. M. \& Honkala, B. H., tech. coords. 1990. Silvics of North America: 1. Conifers. Agriculture Handbook 654. Washington, DC. vol.1, 877 p.

Cain, M.J. 2008. Wisconsin's wetland regulatory program. Wisconsin Department of Natural Resources. Retrieved from dnr.wi.gov/topic/wetlands/documents

Clare, S., Krogman, N., Foote, L., \& Lemphers, N. 2011. Where is the avoidance in the implementation of wetland law and policy? Wetland Ecology and Management, 19(2): 165-182.

Collier, D. 1991. The Comparative Method: Two Decades of Change. Comparative Political Dynamics: Global Research Perspectives, HarperCollins Publishers, 1991.

Curtis, K.J., Voss, P.R., \& Long, D.D. Spatial variation in poverty-generating processes: Child poverty in the United States. 2012. Social Science Research, 41: 146-159.

Dahl, T.E. \& Allord, G.J. 1997. National Water Summary on Wetland Resources.U.S. Geological Survey Water Supply Paper 2425.

deLeon, P. \& deLeon, L. 2004. What ever happened to policy implementation? An alternative approach. Public Administration Research and Theory: J-PART, 12(4): 467-492.

Fischer, F., Miller, G., \& Sidney, M. (Eds.). (2007). Handbook of public policy analysis: Theory, politics, and methods. Boca Raton, FL: CRC Press.

Hill, M. \& Hupe, P. 2014. Implementing Public Policy. $3^{\text {rd }}$ ed. Los Angeles: SAGE Publications.

Homer, C., Dewitz, J., Fry, J., Coan, M., Hossain, N., Larson, C., Herold, N., McKerrow, A., VanDriel, J.N., and Wickham, J. 2007. Completion of the 2001 National Land Cover Database for the Conterminous United States. Photogrammetric

Engineering and Remote Sensing, 73(4): 337-341. 
Homer, C.G., Dewitz, J.A., Yang, L., Jin, S., Danielson, P., Xian, G., Coulston, J., Herold, N.D., Wickham, J.D., and Megown, K., 2015, Completion of the 2011 National Land Cover Database for the conterminous United States-Representing a decade of land cover change information. Photogrammetric Engineering and Remote Sensing, 81(5): 345-354.

Kettlewell, C.I., Bouchard, V., Porej, D., Micacchion, M., Mack, J.J., White, D., \& Fay, L. 2008. An assessment of wetland impacts and compensatory mitigation in the Cuyahoga River Watershed, Ohio, USA. Wetlands, 28(1): 57-67.

Kozich, A.T. \& Halvorsen, K.E. 2012. Compliance with wetland mitigation standards in the Upper Peninsula of Michigan, USA. Environmental Management, 50: 97-105.

Lijphart, A. 1971. Comparative Politics and the Comparative Method. The American Political Science Review, 65(3): 682-693.

Lim, T. 2010. Comparative Politics: An Introduction to Approaches and Issues, $2^{\text {nd }}$ Ed. Boulder, CO: Lynne Rienner Publishers.

Lindsay, R. 2010. Peatbogs and carbon: a critical synthesis to inform policy development in oceanic peat bog conservation and restoration in the context of climate change. University of London. Environmental Research Group. 2010.

MacBeth, M.K. \& Bennett, K. 2001. Rural elected officials, environmental policy, and economic composition. Policy Studies Journal, 29(1): 118-127.

Matland, R.E. 1995. Synthesizing the implementation literature: The ambiguity-conflict model of policy implementation. Journal of Public Administration Research and Theory: J-PART 5(2): 145-174.

McConnell, A. 2010. Policy success, policy failure and grey areas in-between. Public Policy 30(3): 345-362.

Michigan Department of Environmental Quality. 2015. State and Federal Wetland Regulations. Retrieved from http:/michigan.gov/deq

Michigan Department of Natural Resources. 2017. Wetland. Retrieved from http://michigan.gov/dnr

Millennium Ecosystem Assessment. 2005. Ecosystems and Human Well-being: Synthesis. Island Press, Washington, DC. 
Minnesota Board of Water \& Soil Resources. 2015. Wetland Regulation. Retrieved from http://bwsr.state.mn.us/wetlands/regulation

Minnesota Department of Natural Resources. 2015. Shoreland Management. Retrieved from http://www.dnr.state.mn.us/shorelandmgmt

National Oceanic and Atmospheric Administration: Office of Habitat Conservation. 2012. Carbon Sequestration 101. Retrieved from http://habitat.noaa.gov/coastalcarbonsequestration

Owens, K.A. 2008. Understanding how actors influence policy implementation: A comparative study of wetland restorations in New Jersey, Oregon, The Netherland and Finland. Thesis.

Owens, K. \& Zimmerman, C. 2013. Local governance versus centralization: Connecticut wetlands governance as a model. Review of Policy Research, 30(6): 629-656.

Peters, G. 1998. Comparative Politics: Theory and Methods. Washington Square, New York. New York University Press.

Pierce, J.J., Siddiki, S., Jones, M.D., Schumacher, K., Pattison, A., \& Peterson, H. 2014. Social construction and policy design: A review of past applications. The Policy Studies Journal, 42(1): 1-29.

Reyer, J., Wolf, C., \& Murray, M. 2009. Protecting and restoring the kidneys of the Great Lakes: An assessment of wetlands programs in Michigan, Minnesota, Ohio, and Wisconsin. National Wildlife Federation.

Sabatier, P.A. 1986. Top-down and bottom-up approaches to implementation research: A critical analysis and suggested synthesis. Public Policy, 6(1): 21-48.

Sargent, M.S \& Carter, K.S., ed. 1999. Managing Michigan Wildlife: A Landowners Guide. East Lansing, MI: Michigan United Conservation Clubs. 297pp.

Sheldon, D., Granger, T., Hruby, T. Ph.D., Johnson, P., Harper, K., McMillan A., Stanley, S., \& Stockdale, E. 2005. Wetlands in Washington State. Chapter 6: The Science and Effectiveness of Wetland Mitigation. Volume 1 - A Synthesis of the Science.

Schneider, A. \& Ingram, H. 1993. Social construction of target populations: Implications for politics and policy. The American Political Science Review, 87(2): 334-347. 
Scholz, J.T. \& Wang, C. 2006. Cooptation or transformation? Local policy networks and federal regulatory enforcement. American Journal of Political Science, 50(1): 8197.

Stoker, R.P. 1991. Reluctant Partners: Implementing Federal Policy. Pittsburgh, PA: University of Pittsburgh Press.

Turner, K. \& Jones, T. ed. 2009. Wetlands: Market and intervention failures. London: earthscan.

United States Census Bureau / American FactFinder. "S1903 : Median Income in the Past 12 Months (in 2010 Inflation Adjusted Dollars).” 2006 - 2010 American Community Survey 5-year estimates. U.S. Census Bureau's American Community Survey Office, 2010. Retrieved from http://factfinder2.census.gov.

United States Census Bureau / American FactFinder. "P001 : Total Population [1].” 2000 Census.U.S. Census Bureau, 2000. Retrieved from http://factfinder2.census.gov.

United States Census Bureau / American FactFinder. "P1 : Total Population." 2010 Census.U.S. Census Bureau, 2010. Retrieved from http://factfinder2.census.gov.

United States Census Bureau / American FactFinder. "P2 : Urban and Rural." 2010 Census.U.S. Census Bureau, 2010. Retrieved from http://factfinder2.census.gov.

USDA, Economic Research Service. 2003 Metro Classification using U.S. Census Bureau, 2010 data.

USDA NASS. 2007. Census of Agriculture, Quick Stats. Retrieved from https://quickstats.nass.usda.gov.

United States Environmental Protection Agency. 2014. Clean Water Act, Section 404. Retrieved from http://water.epa.gov/lawsregs/guidance/wetlands/sec404

United States Environmental Protection Agency. 2016. National Wetland Condition Assessment: A collaborative survey of the nation's wetlands. Retrieved from https://www.epa.gov/national-aquatic-resource-surveys/nwca

United States Environmental Protection Agency. 2016. Wetlands: What are wetland functions? Retrieved from https://www.epa.gov/wetlands/what-are-wetlandfunctions

United States Fish \& Wildlife Service. 2015. Listed species believed to or known to occur in Michigan. The Environmental Conservation Online System. Retrieved from https://ecos.fws.gov 
Williams, R.L. and R.L. Winkler. 2013. Protected Lands and Net Migration by Age: New Data, More Evidence. Presentation to the International Symposium for Society and Resource Management. Estes Park, CO. June 6, 2013.

Winkler, R. L. 2010. Do natural amenities drive destination development? Rural destinations and their uneven development across the United States. In Rural destinations, uneven development, and social exclusion (pp. 31-74). Diss. University of Wisconsin-Madison, 2010.

Wisconsin Department of Natural Resources. 2008. Shoreland \& Wetland Zoning. Retrieved from http://dnr.wi.gov/topic/ShorelandZoning

Wisconsin Wetlands Association. 2002. Wetland Rules \& Regulations. Retrieved from $\mathrm{http} / / / \mathrm{www} . w i s c o n s i n w e t l a n d s . o r g /$ protectingregulations 


\section{Appendix A. Interview Questions}

I'd like to start by asking you some general questions about your job. What are the goals or responsibilities of your organization?

What are your job responsibilities?

In the course of making planning and zoning decisions, what are the competing interests or goals that you have to balance?

Do you run into situations where you kind of have to balance two or more different goals?

Are there any policies you deal with that have competing or conflicting goals?

Who or what is most demanding your time and what do they want from you?

Is your county seeing much population growth? Are you seeing any impacts from that in terms of development pressure?

I'd like to shift now to talk more about agriculture. How important is agriculture to your county?

What kinds of farming are done? 
Are they mostly large farms or smaller ones?

How does the agriculture in your county compare to other Minnesota counties you know about?

What kinds of pressures are farmers in your county under?

Do you see farmers pushing to expand their production area?

Do you get many farmers looking for wetland permits? Why do you think so (or why not)?

What else has a significant impact on development or the economy in the county?

I'm particularly interested in wetland permitting. If someone in your county wants to develop on a wetland area, what is the process they would need to go through?

How do you make decisions regarding wetland permitting?

What are the policies that you follow when deciding whether or not to give a permit?

What pressures do you face when making decisions regarding wetland permitting? (If no real response) Are there some people or organizations that are kind of pressuring you to grant most permits or to not grant permits? Or do you feel any under the radar pressure coming from people or organizations in the local area or statewide or elsewhere? 
From your experience, how concerned are people in your local community with wetland issues? What matters to them with regards to wetlands?

Is there anything else that you think I should know about how wetland policy is done in your county or in the state of Minnesota in general?

Is there anyone else that would know about how wetlands are handled in XXXXXX county that you think I should talk to? 


\section{Appendix B. Regression Analysis}

To determine if population pressure and agriculture were still impacting wetland area in the Upper Great Lakes states, a multivariate OLS regression model was used for all counties in Michigan, Minnesota, and Wisconsin $(n=242)$ using the variables outlined in Table 6 . This model estimates relationships between population pressure, agriculture, and wetland area change.

Table 6. Dependent and Independent Variables for Regression Analysis

\begin{tabular}{|c|c|c|c|}
\hline Variable Name & Mean & $\begin{array}{l}\text { Standard } \\
\text { Deviation }\end{array}$ & Data Source \\
\hline $\begin{array}{l}\text { Wetland Area Change } \\
2001-2011\end{array}$ & -64.83 & 1167.90 & $\begin{array}{l}\text { Homer, C., Dewitz, J., Fry, J., Coan, M., Hossain, N., Larson, C., Herold, N., } \\
\text { McKerrow, A., VanDriel, J.N., and Wickham, J. 2007. Completion of the } 2001 \\
\text { National Land Cover Database for the Conterminous United States. Photogrammetric } \\
\text { Engineering and Remote Sensing, Vol. 73, No. 4, pp 337-341. } \\
\text { Homer, C.G., Dewitz, J.A., Yang, L., Jin, S., Danielson, P., Xian, G., Coulston, J., } \\
\text { Herold, N.D., Wickham, J.D., and Megown, K., 2015, Completion of the } 2011 \\
\text { National Land Cover Database for the conterminous United States-Representing a } \\
\text { decade of land cover change information. Photogrammetric Engineering and Remote } \\
\text { Sensing, v. 81, no. 5, p. 345-354. }\end{array}$ \\
\hline $\begin{array}{l}\text { Percent Land Area in } \\
\text { Agriculture/Farm } 2010 \\
\end{array}$ & 46.36 & 29.80 & $\begin{array}{l}\text { USDA NASS. 2007. Census of Agriculture, Quick Stats. } \\
<\text { https://quickstats.nass.usda.gov>. }\end{array}$ \\
\hline $\begin{array}{l}\text { Population Density } \\
2010\end{array}$ & 0.00 & 1.67 & $\begin{array}{l}\text { United States Census Bureau / American FactFinder. "P1: Total Population." } 2010 \\
\text { Census.U.S. Census Bureau, 2010. <http://factfinder2.census.gov>. } \\
\text { United States Census Bureau / American FactFinder. "P2 : Urban and Rural." } 2010 \\
\text { Census.U.S. Census Bureau, 2010. <http://factfinder2.census.gov>. } \\
\text { USDA, Economic Research Service. } 2003 \text { Metro Classification using U.S. Census } \\
\text { Bureau, } 2010 \text { data. }\end{array}$ \\
\hline $\begin{array}{l}\text { Population Growth } \\
2000-2010\end{array}$ & 0.00 & 1.12 & $\begin{array}{l}\text { United States Census Bureau / American FactFinder. "P1 : Total Population." } 2010 \\
\text { Census.U.S. Census Bureau, 2010. <http://factfinder2.census.gov>. } \\
\text { United States Census Bureau / American FactFinder. "P001 : Total Population [1]." } \\
2000 \text { Census.U.S. Census Bureau, 2000. <http://factfinder2.census.gov>. }\end{array}$ \\
\hline $\begin{array}{l}\text { Destination } \\
\text { Development } 2000\end{array}$ & 0.36 & 0.18 & $\begin{array}{l}\text { Winkler, R. L. (2010). Do natural amenities drive destination development? Rural } \\
\text { destinations and their uneven development across the United States. In Rural } \\
\text { destinations, uneven development, and social exclusion (pp. 31-74). Diss. University } \\
\text { of Wisconsin-Madison, 2010. }\end{array}$ \\
\hline $\begin{array}{l}\text { Median Household } \\
\text { Income } 2010\end{array}$ & 47086.82 & 8931.33 & $\begin{array}{l}\text { United States Census Bureau / American FactFinder. “S1903 : MEDIAN INCOME } \\
\text { IN THE PAST } 12 \text { MONTHS (IN 2010 INFLATION-ADJUSTED DOLLARS).” } \\
2006 \text { - 2010 American Community Survey 5-year estimates. U.S. Census Bureau's } \\
\text { American Community Survey Office, 2010. <http://factfinder2.census.gov>. }\end{array}$ \\
\hline $\begin{array}{l}\text { Percent Protected } \\
\text { Federal Land Area } \\
2010\end{array}$ & 6.18 & 16.23 & $\begin{array}{l}\text { Williams, R.L. and R.L. Winkler. 2013. Protected Lands and Net Migration by Age: } \\
\text { New Data, More Evidence. Presentation to the International Symposium for Society } \\
\text { and Resource Management. Estes Park, CO. June 6, 2013. }\end{array}$ \\
\hline $\begin{array}{l}\text { Total Wetland Area } \\
2011\end{array}$ & 91607.49 & 175183.98 & $\begin{array}{l}\text { Homer, C.G., Dewitz, J.A., Yang, L., Jin, S., Danielson, P., Xian, G., Coulston, J., } \\
\text { Herold, N.D., Wickham, J.D., and Megown, K., 2015, Completion of the } 2011 \\
\text { National Land Cover Database for the conterminous United States-Representing a } \\
\text { decade of land cover change information. Photogrammetric Engineering and Remote } \\
\text { Sensing, v. 81, no. 5, p. 345-354. }\end{array}$ \\
\hline
\end{tabular}


The dependent variable, wetland area change, is the result of the calculations described in the section on wetland change. Percent land area in agriculture/farm is included as an independent variable in the analysis, because agriculture is one of the main drivers of wetland loss nationwide. Population pressure and related development are the other primary cause of wetland loss, so multiple population related variables were also included. To create the population pressure indexes, a Principal Components Analysis was conducted in Stata of five variables related to population pressure: change in population 2000-2010, total population 2010, change in housing units 2000-2010, metropolitan status 2010, and percent rural area 2010. The results are shown in Table 7. Components 1 and 2 are significant as they both have an Eigenvalue greater than 1 . Component 1 (urban) is an index for population density, and Component 2 (growth) is an index for population growth.

Table 7. Principal Components Analysis Results

\begin{tabular}{|l|r|r|r|r|}
\hline Component & Eigenvalue & Difference & Proportion & Cumulative \\
\hline 1 & 2.782 & 1.518 & 0.557 & 0.557 \\
\hline 2 & 1.265 & 0.702 & 0.253 & 0.809 \\
\hline 3 & 0.562 & 0.191 & 0.112 & 0.922 \\
\hline 4 & 0.372 & 0.352 & 0.074 & 0.996 \\
\hline 5 & 0.019 & & 0.004 & 1.000 \\
\hline & & \multicolumn{2}{|c|}{ Component } \\
\cline { 2 - 5 } Variables & \multicolumn{2}{|c|}{0.173} & 0.847 \\
\hline Population Change 2000-2010 & 0.535 & 0.219 \\
\hline Change in Housing Units 2000-2010 & 0.456 & -0.479 \\
\hline Total Population 2010 & 0.477 & -0.014 \\
\hline Metropolitan Status 2010 & -0.499 & 0.078 \\
\hline Percent Rural Area 2010 & & \\
\hline
\end{tabular}


The destination development variable is a composite measure that is meant to capture population pressure in more rural lakes-destination areas due to seasonal housing and counter-urbanization (often of retirees). It is based on data from Census 2000 and includes the proportion of housing units for seasonal or recreational use, the proportion of residents that are recent in-migrants from a metropolitan area, and proportion of owner occupied housing units valued at $\$ 200,000$ or more.

Median household income is included in the analysis as a control variable to account for the different economic environment between counties and its effects on wetland loss. Percent federal protected land is included to account for areas where wetland impacts are prohibited. Total wetland area is included to account for the fact that places with greater wetland area will likely see greater change than places with less wetland area.

First, a global model was conducted at the county level to assess the relationships between variables across the region as a whole. Second, tests for model specification and fit were conducted for the global model. Because each of the three states has passed varying versions of wetlands policy and implements the federal Section 404 policy differently, we might expect that relationships between agricultural, population pressure, and wetland area change could vary from state to state, especially if these policies are more effective in some states than others. Spatial regime modeling addresses large-scale spatial heterogeneity (Curtis et al. 2012), so spatial regime models can be used to test for state-level differences in relationships. This is simply an OLS regression model that is run separately for each state, allowing results for each state to be compared. Based on 
findings from the model fit tests for the global model, spatial regime models were conducted separately for each state to account for state-level effects and to test for spatial relationships between counties in each state, followed by tests for model fitness for the spatial regime model of each state.

Results of the global model, which includes all counties in all three states, suggest that high population density is associated with wetland loss, but the global model has a low $\mathrm{r}^{2}$ value of 0.104 , high heteroskedasticity $\left(\mathrm{chi}^{2}=23.14\right)$, and evidence of spatial autocorrelation (Moran's I = 0.299), indicating that the model is not a good fit (Table 8). There are high residuals in Minnesota and low residuals in Michigan, while Wisconsin falls somewhere in the middle (Figure 4), meaning the global model is a better fit for Michigan than Wisconsin or Minnesota. This, along with the finding of significant heteroskedasticity, suggests that something different is impacting wetland area, particularly in Minnesota than the other two states. 
Table 8. Regression Results for Global and State Models

\begin{tabular}{|c|c|c|c|c|c|c|}
\hline \multirow[b]{2}{*}{ Model } & \multirow[b]{2}{*}{ Independent Variables } & \multicolumn{2}{|c|}{$\begin{array}{c}\text { Unstandardized } \\
\text { Coefficients }\end{array}$} & \multirow{2}{*}{\begin{tabular}{|l}
$\begin{array}{l}\text { Standardized } \\
\text { Coefficients }\end{array}$ \\
Beta
\end{tabular}} & \multirow[b]{2}{*}{$\mathrm{t}$} & \multirow[b]{2}{*}{ Sig. } \\
\hline & & $\mathrm{B}$ & Std. Error & & & \\
\hline Global & Median Income 2010 & -0.015 & 0.012 & -0.111 & -1.24 & 0.218 \\
\hline Adj $r^{2}=0.104$ & Percent Ag 2010 & -1.406 & 4.021 & -0.036 & -0.35 & 0.727 \\
\hline $\mathrm{chi}^{2}=23.14$ & Destination Development 2000 & -574.375 & 583.134 & -0.086 & -0.98 & 0.326 \\
\hline prob $>\mathrm{chi}^{2}=0.000$ & Population Density 2010 & -122.748 & 58.519 & -0.175 & -2.10 & $\mathbf{0 . 0 3 7}$ \\
\hline Moran's i $=0.299$ & Population Growth 2000-2010 & -23.529 & 66.963 & -0.023 & -0.35 & 0.726 \\
\hline \multirow[t]{2}{*}{$\mathrm{p}=0.000$} & Percent Protected Land 2010 & -71.324 & 31.654 & -0.150 & -2.25 & 0.025 \\
\hline & Acres of Wetland 2011 & 0.001 & 0.000 & 0.155 & 2.17 & $\mathbf{0 . 0 3 1}$ \\
\hline Michigan & Median Income 2010 & -0.005 & 0.003 & -0.183 & -1.50 & 0.138 \\
\hline Adj $r^{2}=0.417$ & Percent Ag 2010 & 1.386 & 1.026 & 0.169 & 1.35 & 0.181 \\
\hline $\operatorname{chi}^{2}=0.73$ & Destination Development 2000 & 57.022 & 136.805 & 0.046 & 0.42 & 0.678 \\
\hline prob $>\operatorname{chi}^{2}=0.393$ & Population Density 2010 & -64.689 & 13.971 & -0.570 & -4.63 & 0.000 \\
\hline Moran's i $=0.165$ & Population Growth 2000-2010 & -2.933 & 9.919 & -0.027 & -0.30 & 0.768 \\
\hline \multirow{2}{*}{$\mathrm{p}=0.006$} & Percent Protected Land 2010 & -14.744 & 8.385 & -0.159 & -1.76 & 0.083 \\
\hline & Acres of Wetland 2011 & 0.000 & 0.000 & -0.079 & -0.75 & 0.457 \\
\hline Minnesota & Median Income 2010 & -0.002 & 0.038 & -0.008 & -0.04 & 0.965 \\
\hline Adj $r^{2}=0.164$ & Percent Ag 2010 & -23.234 & 11.589 & -0.363 & -2.00 & 0.048 \\
\hline $\operatorname{chi}^{2}=11.28$ & Destination Development 2000 & -3140.462 & 1758.658 & -0.257 & -1.79 & 0.078 \\
\hline prob $>\operatorname{chi}^{2}=0.001$ & Population Density 2010 & -383.759 & $\mathbf{1 7 2 . 8 3 7}$ & -0.333 & -2.22 & 0.029 \\
\hline Moran's i $=0.183$ & Population Growth 2000-2010 & -189.068 & 634.817 & -0.045 & -0.30 & 0.767 \\
\hline \multirow[t]{2}{*}{$\mathrm{p}=0.001$} & Percent Protected Land 2010 & -81.558 & 63.849 & -0.147 & -1.28 & 0.205 \\
\hline & Acres of Wetland 2011 & 0.000 & 0.001 & 0.055 & 0.40 & 0.687 \\
\hline Wisconsin & Median Income 2010 & -0.019 & 0.008 & -0.375 & -2.27 & 0.027 \\
\hline Adj $\mathrm{r}^{2}=0.171$ & Percent Ag 2010 & 10.256 & 3.619 & 0.598 & 2.83 & 0.006 \\
\hline $\operatorname{chi}^{2}=2.75$ & Destination Development 2000 & 330.541 & 407.217 & 0.131 & 0.81 & 0.420 \\
\hline prob $>$ chi $^{2}=0.097$ & Population Density 2010 & -11.240 & 40.358 & -0.043 & -0.28 & 0.782 \\
\hline Moran's $\mathrm{i}=0.073$ & Population Growth 2000-2010 & -120.044 & 129.327 & -0.121 & -0.93 & 0.357 \\
\hline \multirow[t]{2}{*}{$\mathrm{p}=0.212$} & Percent Protected Land 2010 & -14.099 & 71.090 & -0.027 & -0.20 & 0.843 \\
\hline & Acres of Wetland 2011 & 0.000 & 0.001 & 0.001 & 0.01 & 0.995 \\
\hline
\end{tabular}

Note: Variables highlighted and in bold are statistically significant at $\mathrm{p}<0.05$

Running the model separately for each state (regime model) provided a better fit

in each state, in comparison to the global model; however, together, these models suggest that traditional drivers of wetland change (population and agricultural pressure) don't explain county-level variation in wetland area change well. The regime models suggest that relationships between agricultural and population pressure and wetland area change 
vary by state. In Minnesota, greater population density and greater agricultural land area look to predict wetland loss.

Despite these improvements, the regime model for Minnesota still suggests there is significant unexplained spatial variance. The model has a high level of heteroskedasticity at the county level $\left(\mathrm{chi}^{2}=11.28\right)$, meaning that there is variance in error for wetland area change between counties in Minnesota, and there is a high level of spatial autocorrelation (Moran's I $=0.183$ ). This remaining county-level variance and spatial autocorrelation suggests that there is something more going on that differentiates the process of wetland change in Minnesota that is not explained by the regression models 


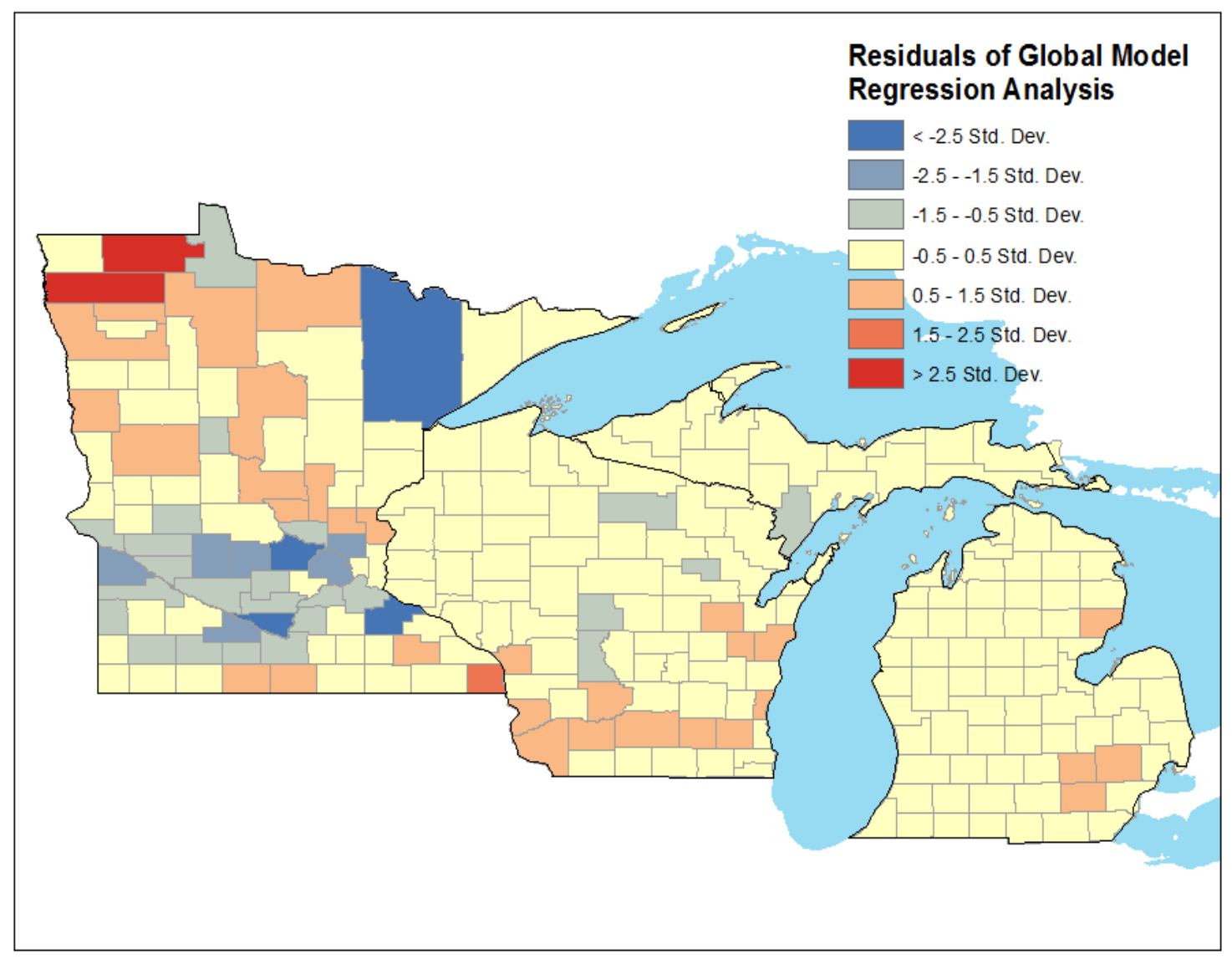

Figure 4. Residuals of global model regression results 